\title{
1. Industry and atrocity: the business and human rights context
}

There is a problem with the global economy. Transnational corporations can impact negatively, and in substantial ways, upon human rights and the environment in the conduct of their global business. Too often when they do, they do so with impunity. This much is, at least, now beyond dispute. Whether it is worker deaths in unsafe textile factories, violence against local communities committed by mining security or damage to health, environments and livelihoods due to oil flaring and oil spills, allegations of corporate-related human rights abuses and environmental damage become news on an almost daily basis. ${ }^{1}$ Less evident are the mechanisms for accountability for such harms. The United Nations (UN) Special Representative of the Secretary General on Business and Human Rights, John Ruggie (the SRSG), described the problem as a function of globalisation. Governance gaps have become apparent where prevailing national and international regulatory frameworks have failed to manage forces of economic globalisation whose push can drive adverse consequences. The result is a "permissive environment for wrongful acts by companies of all kinds without adequate sanctioning or reparation". ${ }^{2}$

The governance gap described by the SRSG raises a number of questions, not least of which is the accountability of companies when harms do occur related to their global business. Accountability is a concept that implies at least two things. The first is answering for one's conduct. The second is facing adverse consequences for one's part in a wrong. ${ }^{3}$ A number of initiatives and standards on business and human rights have proliferated to address either or both of these accountability goals where corporations operate in environments

\footnotetext{
1 For a repository of cases, see: Business and Human Rights Resource Centre, https://www.business-humanrights.org/en/ (accessed 30 April 2021).

2 United Nations Human Rights Council (UNHRC), "Protect, Respect and Remedy: a Framework for Business and Human Rights, Report of the Special Representative of the Secretary-General on the issue of Human Rights and Transnational Corporations and Other Business Enterprises, John Ruggie" (7 April 2008) UN Doc A/HRC/8/5 [3] (hereafter "Framework").

3 Andreas Shedler, "Conceptualizing Accountability" in Andreas Schedler et al (eds), The Self-Restraining State: Power and Accountability in New Democracies (Lynne Rienner Publishers 1999) p 13.
} 
tending towards under-regulation or under-enforcement of law. ${ }^{4}$ Frustrations over the limits of these, largely voluntary, initiatives have led to a greater drive towards mechanisms of formal legal accountability for corporate related harms. ${ }^{5}$ Human rights have been the natural vehicle for much of this discourse on global business, governance and accountability. With growing economic and political clout, transnational corporations have been described as the leviathans of our time. ${ }^{6}$ Human rights have proven a resilient and powerful universalist vernacular aimed at speaking obligation to power. ${ }^{7}$

Though less well known, a parallel discussion has been taking place within international criminal law. International criminal law, sometimes referred to as atrocity law, ${ }^{8}$ is a specialised field of international law that applies the criminal law lens to egregious harms - extraordinary crimes or crimes of mass atrocity. Whilst it has some claim to an ancient pedigree, ${ }^{9}$ atrocity law as it is known today emerged after World War II when the Allied nations established criminal tribunals to prosecute individuals for Axis conduct before and during the war. Named after the cities in which they were held, Nuremberg and Tokyo, these proceedings and the laws they applied had sufficient international dimensions and support to found the basis of a discrete field of international law. It is a field that has grown exponentially in recent decades. Its major revelation is the legal principle that certain international norms apply directly to individuals in respect of particular misconduct. This permits the punishment of wrongdoers regardless of the status of their conduct under domestic law. Originally, the principle of individual criminal responsibility was grounded primarily in natural law theory and the idea that some wrongs are, by their nature, so egregious and offensive to humanity that their criminal status is self-evident.

4 For a summary of initiatives and standards, see UNCHR, "Report of the United Nations High Commissioner on Human Rights on the Responsibilities of Transnational and Related Business Enterprises with regard to Human Rights" (15 February 2005) UN Doc E/CN.4/2005/91 Annexes II and III.

5 See, e.g. International Council on Human Rights Policy (ICHRP), Beyond Voluntarism: Human Rights and the Developing International Legal Obligations of Companies (ICHRP February 2002) Ch II.

6 Sarah Joseph, "Taming the Leviathans: Multinational Enterprises and Human Right” (1999) 46 NILR 171.

7 See, e.g. Charles Beitz who writes, "To whatever extent contemporary international political life can be said to have ... a 'sense of justice,' its language is the language of human rights": Charles Beitz, "What Human Rights Mean” (2003) Daedalus 36,40 .

8 David J. Scheffer, "The Future of Atrocity Law" (2002) 25(3) Suffolk Transnat'1 L.Rev. 389. The terms international criminal law and atrocity law are used interchangeably in this book.

9 See, e.g. Kevin Jon Heller and Gerry Simpson (eds), The Hidden Histories of War Crimes Trials (OUP 2013) Pt I. 
However, as international criminal law develops, individual accountability for international crimes is increasingly supported by legal positivism. ${ }^{10}$

While there is some debate about what constitutes international crimes, the most common definition is those offences giving rise to criminal responsibility directly under international law. ${ }^{11}$ By this definition, there are four categories of international crimes, each of which prohibits a range of conduct with certain unifying qualities. These are crimes against humanity, genocide, war crimes and the crime of aggression. Briefly put, crimes against humanity are certain prohibited behaviours committed as part of systematic or widespread violence against civilians, whether during peace or war. ${ }^{12}$ Genocide refers to certain prohibited conduct (for example killing or attempting to prevent births) undertaken with the intent to destroy, in whole or in part, a national, ethnical, racial or religious group. ${ }^{13}$ War crimes cover a wide range of conduct committed during armed conflict that are illegal under the laws of war and that are particularly egregious. Examples include summary executions, torture, attacks on protected (generally vulnerable) persons and objects, and pillaging places or towns. ${ }^{14}$ Aggression means the use of armed force by a state against another state that is not justified under international law. ${ }^{15}$

Despite the onerous elements involved in characterising an act or omission as an international crime, there are cases that illustrate the potential for corporate involvement in such crimes. As early as the Nuremberg trials, major German industrialists were pursued in the context of a prosecutorial program directed at those most responsible for the atrocities of the war. The industrialists' crimes, which were committed through the instrumentality of their corporations, included: helping prepare the state for aggressive war, using slave labour generated by the war (infamously, the German IG Farben corporation situated its main synthetic rubber manufacturing plant adjacent to the Auschwitz concentration camp) and for the spoliation (taking by force)

10 See, e.g. on the move in international criminal law from being grounded primarily in substantive justice to one increasingly grounded in strict legality: Antonio Cassese et al, Cassese's International Criminal Law, 3rd edn (OUP 2013) pp 22-27.

11 Roger O'Keefe, International Criminal Law (OUP 2015) p 51. On definitional debates, see Robert Cryer et al, An Introduction to International Criminal Law and Procedure, 4th edn (CUP 2019) pp 3-8.

12 See, e.g. Rome Statute of the International Criminal Court (opened for signature 17 July 1998, entered into force 1 July 2002) 2187 UNTS 90 ("Rome Statute") art 7.

13 Rome Statute art 6; Convention on the Prevention and Punishment of the Crime of Genocide (adopted 9 December 1948, entered into force 12 January 1951) 78 UNTS 277 (Genocide Convention) art 2.

14 Rome Statute, (fn 12) art 8.

15 Rome Statute, art 8 bis. 
of Jewish businesses and property in occupied territories. ${ }^{16}$ Contemporary examples also exist, many of which have founded civil claims in the United States under the unique Alien Torts Statute. ${ }^{17}$ Ways in which companies might today be implicated in international crimes include: the role of private military companies in the torture of prisoners within their custody; militarised commerce - the use of military or para-military forces as security for mining operations and associated abuses; ${ }^{18}$ slave labour within business supply chains; the funding and supply of armed conflict through business networks; and the commercial theft of goods and natural resources in conflict contexts. ${ }^{19}$ It was this practical reality, of businesses involved in atrocity crimes, that in part prompted a proposal that the International Criminal Court (ICC) should have jurisdiction not only over natural persons but also over corporations. ${ }^{20}$ The ICC proposal failed but the debate continues.

In light of the potential for corporations to participate in, and benefit from, international crimes, what is the appropriate role to be played by atrocity law in addressing corporate wrongs? In some respects, the field can seem categorically ill-suited to the task given criminal law's emphasis upon human agency and international law's state-centeredness. To what extent do the central concerns of international criminal law nonetheless properly speak to corporate activity that is, generally, directed at the presumptively lawful goal of productivity and profit? Can international criminal law serve as an appropriate corporate accountability tool, as has been stipulated in the business and human rights literature, or is it the wrong avenue for us to pursue? To what extent does the internal coherence of atrocity law itself demand engagement with the business case? This book aims to address these questions, ultimately arguing, alongside other contemporaries, that industry does and ought to fall within the purview of international criminal law, in terms of both individual and corporate responsibility.

More explicitly, the aim of this book is two-fold. First, it is to expose those who are unfamiliar with the subject to the general range of cases and initiatives related to business within the modern field of international criminal law.

\footnotetext{
16 See further $\mathrm{Ch} 2$.

1728 USC ss 1350.

18 Craig Forcese, “Deterring 'Militarized Commerce': The Prospect of Liability for 'Privatized’ Human Rights Abuses” (2000) 31 Ottawa L.Rev. 171, 173-5.

19 For a typology of fact scenarios, see International Commission of Jurists (ICJ), Report of the International Commission of Jurists Expert Legal Panel on Corporate Complicity in International Crimes (ICJ 2008) Vol 2, 37-48; Wolfgang Kaleck and Miriam Saage-Maa $\beta$, "Corporate Accountability for Human Rights Violations Amounting to International Crimes: The Status Quo and its Challenges" (2010) 8(3) JICJ 699, 700-709.

20 See further Ch 3.
} 
Second, it is to explore and analyse the major debates that the moves towards corporate accountability under international criminal law have prompted. The book will thus, it is hoped, be of value to both the uninitiated (in terms of cataloguing the major moments that interplay with the question of business involvement in atrocity) but also to the initiated (in terms of the analysis of debates regarding corporate accountability under international criminal law).

In order to achieve the first aim, the book explores the modern history of international criminal law (Nuremberg and beyond) to tease out the degree to which the principles and institutions of the field have engaged with, or have omitted, the role of business in atrocity. This includes a chapter on transitional justice more generally (Ch 5) on the basis that the potential and limits of international criminal law can be better understood when looked at as a modality of this broader field. Attention to business actors has been at best marginal in international criminal practice to date, despite repeated statements of intent by prosecutors to prosecute business actors for their part in international crimes. ${ }^{21}$ Moreover, no court or tribunal has yet exercised jurisdiction over corporations (as opposed to individuals) for international crimes. Nonetheless, examples of prosecutions under international criminal law do exist, albeit of natural persons operating in business contexts rather than the corporate entity per se. There have also been several initiatives and steps towards corporate prosecutions that are noteworthy. The book follows experiences from after World War II through to recent efforts in international criminal and transitional justice (Chs $2-5$ ) to illustrate that the role of industry in atrocity has been a significant undercurrent in efforts to respond to atrocity crimes to date.

In order to achieve the second aim, the book engages with a range of doctrinal and normative debates prompted by the proposition of corporate accountability under international criminal law. Such debates are addressed both as they arise in the context of the relevant initiatives or jurisprudence to which they relate (Chs 2-5), as well as in a dedicated chapter (Ch 6).

The current chapter is designed as an introduction to the core of the work. By situating the subsequent discussion on atrocity law within the broader business and human rights discourse, this chapter contextualises the contemporary drive for solutions that implicates international criminal law and its anti-impunity, pro-punishment function. It is structured as follows. Part I defines the subjects of this study, in particular the transnational corporation, and provides some information about their significance within the modern economy. It then out-

21 Joanna Kyriakakis, "Justice after War: Economic Actors, Economic Crimes, and the Moral Imperative for Accountability after War" in Larry May and Andrew T. Forcehimes (eds), Morality, “Jus Post Bellum”, and International Law (CUP 2012) pp $115-120$. 
lines the mechanics of the governance gap, what it comprises, what it implies and some of the principle international efforts to address the phenomenon. It focusses, in particular, upon the implications for international criminal law of the outcome of the SRSG's work. Part II then turns to international criminal law, to introduce the potential and challenges of the application of the field to the prosecution of corporations involved in atrocity.

Before going further, it is worth clarifying certain terminology used in the book. First, as noted above, the term "accountability" can denote any range of processes or mechanisms that are directed at causing a person to answer for their conduct and to face adverse consequences for their part in a wrong. However, the interest animating this work is the role for formal law in relation to business and human rights, based on a view that, in this area, soft law measures alone have proven inadequate. For this reason, where used, "accountability" denotes legal accountability, meaning mechanisms of formal legal institutions directed at those two goals, unless otherwise indicated. The term "liability" is therefore also used interchangeably with accountability. Moreover, as much of the content of this book (but not all) relates to the criminal law, the term responsibility is used to denote the existence of a legal duty under the criminal law. Second, international criminal law is used to refer to both the body of rules comprising the proscription of international crimes (the substantive law), as well as the institutional processes for their enforcement. With regard to the latter, this encompasses institutions that apply and enforce international criminal norms, even where those institutions have concurrent jurisdiction to apply other sources of law. It thus includes hybrid courts and tribunals, and domestic courts to the extent that they apply international criminal norms. Finally, the term "industry" is used from time to time, in its broadest form as referring to any commercial activity or enterprise. The term's dual implication of the commercial activity and those prominent individuals involved in it and regarded as an entity is part of the attraction of this term.

\section{CORPORATIONS AND HUMAN RIGHTS}

\section{Transnational Corporations}

Transnational corporations are the most significant form of business association when we consider accountability challenges wrought by an increasingly globalised economy. A transnational corporation can be described as a legal person that "owns or controls production or service facilities outside the 
country in which it is based". ${ }^{22}$ There are in fact many terms used to describe a similar phenomenon, including "multinational corporation", "multinational enterprise" or "transnational enterprise". ${ }^{23}$ Generally common to these terms is that, rather than denote a single corporation, they aim to capture the range of ways in which clusters of corporations or economic entities operating across national borders ${ }^{24}$ are integrated into a "unified corporate strategy" 25 or an "autonomous corporate system". ${ }^{26}$ As a result of their cross-border integration through officially disaggregated business entities, transnational corporations create distinct challenges to the "development of economic policy in the states where they operate" relative to wholly national companies. ${ }^{27}$

While many terms abound, the preference for a certain term can aim to highlight particular characteristics of the phenomenon pertinent to the matter at hand. ${ }^{28}$ So, for example, Clapham notes that the term "transnational corporation", which is generally preferred in this book, "emphasizes that there is usually a single legal corporation operating in more than one country, with

22 Menno T. Kamminga, "Holding Multinational Corporations Accountable for Human Rights Abuses: A Challenge for the European Community" in Philip Alston (ed), The EU and Human Rights (OUP 1999) p 553.

23. For a discussion of definitional issues, see Peter T. Muchlinski, Multinational Enterprises and the Law, 2nd edn (OUP 2007) pp 5-8.

24 For example, the definition of transnational corporations contained in a set of UN draft norms on corporations and human rights is, "an economic entity operating in more than one country or a cluster of economic entities operating in two or more countrieswhatever their legal form, whether in their home country or country of activity, and whether taken individually or collectively": UNCHR (Sub-Commission), "Norms on the Responsibility of Transnational Companies and Other Business Enterprises with regard to Human Rights" (26 August 2003) UN Doc E/CN/.4/Sub.2/2003/12/Rev.2 [20] (hereafter "the Draft Norms").

${ }_{25}$ Menno T. Kamminga and Saman Zia-Zarifi, "Liability of Multinational Corporations under International Law: An Introduction" in Menno T. Kamminga and Saman Zia-Zarifi (eds), Liability of Multinational Corporations under International Law (Kluwer Law 2000) p 2. See also, Gralf-Peter Calliess, "Introduction: Transnational Corporations Revisited" (2011) 18(2) Ind.J.Global Legal Studies 601, 604, describing forms through which such integration can occur.

26 "The concept of transnationality comes into its own when it is applied to an autonomous corporate system and, in this sense, the transnational corporation is one single corporation even if it is composed of corporations with separate identities under the corporation law of the States in which they operate": Francois Rigaux, "Transnational Corporations" in Mohammed Bedjaoui (ed), International Law: Achievements and Prospects (Martinus Nijhoff 1991) p 124.

27 Muchlinski, Multinational Enterprises and the Law (2007) (fn 23) p 8.

28 Andrew Clapham, Human Rights Obligations of Non-State Actors (OUP 2006) p 201. Another basis for choosing one term over another can relate to historical associations with the usage of particular terms: Kamminga and Zia-Zarifi, "Liability of Multinational Corporations under International Law: An Introduction” (2000) (fn 25) 3. 
a headquarters and a legal status incorporated in the national law of the home state". ${ }^{29}$ The association of the transnational corporation with a discernible "home" state-usually defined as the country in which the parent company of a corporate group is incorporated or has its principal place of businesshighlights the particular international interest in, and concern about, the operations of foreign directed corporations operating in the developing world. ${ }^{30}$ In other words, the term "trans-nationality" tends to highlight the capacity of large modern corporations to operate across national borders and alerts us to the question of where they tend to cross from and into. This might, in turn, tell a story of economic colonialism and, in any event, certainly implies something about the prospects for legal regulation, namely that the home state (and not only the host state) might have a role to play.

By way of contrast, the term "multinational" tends to emphasise the possibility that some corporations may have more than one nationality, ${ }^{31}$ or are increasingly detached from an identifiable home state. For example, it may be that the parent company's board or shareholders comprise members from more than one country. ${ }^{32}$ Generally speaking, transnational corporations continue to be associable with identifiable home states, the bulk of which are a discrete group of northern states (see further below). Notably, they also tend to reflect the managerial and political cultures of their home states. ${ }^{33}$ There is, however, evidence of growing corporate multi-nationality. ${ }^{34}$ Increasing corporate multi-nationality implies something distinct in terms of optimal legal regulatory options and, in particular, may point to the virtues of regulation at the international or the internal (company) level.

While transnational corporations raise particular governance challenges that are discussed below, in the context of dealing with international crimes there is no need to exclude purely national corporations or alternative business associations from the study. An international framework in respect of atrocity has been justified in part on the basis that these are crimes for which there

\footnotetext{
29 Clapham, Human Rights Obligations of Non-State Actors (2006) (fn 28) p 199.

30 Clapham, Human Rights Obligations of Non-State Actors (2006) p 199.

31 Clapham, Human Rights Obligations of Non-State Actors (2006) p 200.

32 This concept is sometimes referred to as the degree of transnationality or internationalisation. For a discussion of the shift from national corporations with international dimensions to corporations with increased detachedness or "footlooseness" from any given nation state, see Calliess, "Introduction: Transnational Corporations Revisited" (2011) (fn 25) 607-10.

33 Paul N. Doremus et al, The Myth of the Global Corporation (Princeton University Press 1999); John Ralston Saul, The Collapse of Globalism and the Reinvention of the World (Atlantic Books 2005) pp 81-83.

34 Calliess, "Introduction: Transnational Corporations Revisited" (2011) (fn 25) 607-10.
} 
is a propensity for perpetrators to escape wholly domestic justice systems. Two reasons for an impunity challenge in respect of international crimes are aptly summarised in the "unwillingness and inability" criteria of the ICC's jurisdictional rules. ${ }^{35}$ In short, international crimes tend to be under-enforced within a wholly state-based justice framework because the state where the offence occurred may be unwilling to act, for example because state agents are implicated in the wrong. Alternatively, the local state may be unable to act, for example because the state's justice system has collapsed due to conflict or failed governance, which itself may be the same environment that enabled atrocity crimes to occur in the first place. Further, some atrocities cross boundaries and affect many states or, though internal to a state, pose peace and security challenges to an entire region, warranting an international justice response. In as much as this is the justifying narrative animating the international criminal justice project, the impunity challenge particular to atrocity crimes is arguably true regardless of the character of the offender, be they natural or corporate, and for the latter, whether nationally based or otherwise. Many of the discussions in this book are therefore not restricted to transnationally operating companies. However, the implications of transnational corporate impunity for atrocity crimes, especially where we are dealing with transnational corporations from the Global North escaping responsibility for violations in the Global South, raises particular challenges and concerns that will be explored throughout the book.

\section{The Significance of Transnational Corporations to the Global Economy}

The transnational corporation is not a peculiarly modern phenomenon. The origin of this form of commercial organisation has been traced to the ancient civilisations of Assyria, Babylonia and Rome. ${ }^{36}$ More commonly though it is the European trading corporations of the 16th to 18th centuries, such as the English East India Company, that are identified as the precursors of the modern multinational, being similar in kind, if not in degree, of "produc-

\footnotetext{
35 Rome Statute (fn 12), art 17.

36 See, e.g. Karl Moore and David Lewis, Birth of the Multinational: 2000 Years of Ancient Business-From Ashur to Augustus (Copenhagen Business School Press 1999); Karl Moore and David Lewis, Foundations of Corporate Empire: Is History Repeating Itself? (Pearson Education Limited 2000); Stanley Bing, Rome Inc.: The Rise and Fall of the First Multinational Corporation (Norton 2006); Philip J Stern, 'The Corporation in History' in Grietje Baars and André Spicer (eds), The Corporation: A Critical, Multi-Disciplinary Handbook (CUP 2017).
} 
tive integration across borders". ${ }^{37}$ This colonial heritage is noteworthy as it indicates the global politics that inhered to progenitors of the modern transnational corporate form. Incorporated in their European home states for the purpose of facilitating overseas trade with the East and with new colonies, these early trading companies were characterised by the grant of monopoly powers and the capacity to protect those monopoly powers in respect of the overseas territories in which they operated for both private and home state gain. ${ }^{38}$ These companies were constituted, to various degrees, by both private and public functions related to the trading and sovereign powers they enjoyed respectively. ${ }^{39}$ They were in large part instruments of colonial expansionism into profitable new territories that, by virtue of being undertaken via the private form, bypassed costs associated with like public action. ${ }^{40}$ As instruments of colonial expansionism, many of these corporations were no strangers to claims of involvement in atrocity crimes. Examples include the role of the European rubber corporations in enforcing and benefitting from the slave labour constitutive of King Leopold's "Congo Free State"41 and the English East Indian Company's direct engagement in successive military coups in Bengal in order to pillage local resources. ${ }^{42}$ Recent studies illustrate correlations between these histories and modern concerns of corporate impunity for atrocity crime and

37 Muchlinski, Multinational Enterprises and the Law (2007) (fn 23) pp 8-9. See also Nick Robins, The Corporation that Changed the World: How the East India Company Shaped the Modern Multinational (Pluto Press 2006) pp 22-38, describing similarities and differences between the East India Company and the modern multinational.

38 Janet McLean, "The Transnational Corporation in History: Lessons for Today?" (2004) 79 Ind.L.J. 363.

39 For examples of the private and public functions of the major trading companies across the different periods of their operation, see McLean, "The Transnational Corporation in History: Lessons for Today?" (2004) 363-73.

40 McLean, "The Transnational Corporation in History: Lessons for Today?" (2004) 365; Steven R. Ratner, "Corporations and Human Rights: A Theory of Legal Responsibility" (2001) 111 Yale J.L. \& Human 443, 452-54; Martti Koskenniemi, The Gentle Civilizer of Nations: The Rise and Fall of International Law 1870-1960 (CUP 2001) pp 117-121, describing the acceleration of European expansion in the 1870s-90s through the revival of chartered companies.

${ }_{41}$ See, e.g. Madelaine Drohan, Making a Killing: How and Why Corporations Use Armed Force to do Business (Lyons Press 2003) Ch 2; Ben Kiernan, "From Irish Famine to Congo Reform: Nineteenth-Century Roots of International Human Rights Law and Activism" in Rene Provost and Payam Akhavan (eds), Confronting Genocide (Springer 2011) pp 26-43.

42 See, e.g. Robins, The Corporation that Changed the World: How the East India Company Shaped the Modern Multinational (2006) (fn 37) Ch 4. 
problematise claims that a strict conceptual divide between public and private actors has long existed on the international plane. ${ }^{43}$

Despite this colonial pedigree, the business and human rights dynamic today is historically unique. ${ }^{44}$ For example, since the turn of the 21 st century, there has been significant growth in the number of transnationally structured business enterprises. The UN Conference on Trade and Development (UNCTAD) estimate that in 2008 there were in existence some 82,000 transnational corporations, with around 810,000 foreign affiliates. ${ }^{45}$ By way of contrast, in 1990 about 35,000 transnational corporations operated worldwide, ${ }^{46}$ while in the early 1970 s there were approximately $7,000 .{ }^{47}$ Calliess describes the situation as an "exploding number and size of private enterprises on a global scale". ${ }^{48}$

The radical growth in the numbers of transnational corporations has been matched by growth in their scale, size, economic significance and influence. One measure often used to illustrate contemporary corporate economic clout is the way in which "economies" internal to major transnational corporations today rival those of states. In 2000, the Institute for Policy Studies revealed that companies make up 51 of the top 100 economies when comparing the gross domestic product of states against corporate revenues. ${ }^{49}$ According to this approach, the economy of General Motors in 1999 was larger than that of Norway. Another measure of significance is the extent of total global trade that occurs within or involving transnational corporations. In 2013, UNCTAD

43 See, e.g. Pepijn Brandon, "Between Company and State: The Dutch East and West India Companies as Brokers Between War and Profit" in Grietje Baars and André Spicer (eds), The Corporation: A Critical, Multi-Disciplinary Handbook (CUP 2017); McLean, "The Transnational Corporation in History: Lessons for Today?" (2004) (fn 38) 374, arguing that "for colonised people, [encounters with] trading corporations and the state may be interchangeable in terms of their effects if not in the meaning attributed to such encounters and the legal categories concerned".

44 For a short history of the four broad epochs in international law's approach to the business and human rights dynamic since the colonial era, see Ratner, "Corporations and Human Rights: A Theory of Legal Responsibility" (2001) (fn 40) 452-60.

45 UNCTAD, World Investment Report 2009-Transnational Corporations, Agricultural Production and Development (UNCTAD 2009) 17.

46 UNCTAD, World Investment Report 1992-Transnational Corporations as Engines of Growth (UNCTAD 1992) 5.

47 John Madeley, Big Business, Poor Peoples: How Transnational Corporations Damage the World's Poor, 2nd edn (Zed Books 2008) p 2.

48 Calliess, "Introduction: Transnational Corporations Revisited" (2011) (fn 25) 601.

49 Sarah Anderson and John Cavanaugh, Top 200: The Rise of Global Corporate Power (Institute for Policy Studies 2000). For a critique of this measure and proposing alternative measures of corporate economic clout, see Brian Roach, "A Primer on Multinational Corporations" in Alfred D. Chandler Jr and Bruce Mazlish (eds), Leviathans: Multinational Corporations and the New Global History (CUP 2005) p 26. 
estimated transnational corporations accounted for 80 per cent of global trade through the international production networks coordinated by them. ${ }^{50}$ These trends have only increased in more recent years, as hyper-globalisation has been marked by a growing concentration of the trade market into a smaller number of dominant transnational corporations, largely through the vehicle of global value chains. ${ }^{51}$ Given this dominance, the capacity of transnational corporations to, among other things, make choices regarding the most cost-effective location of the increasingly fragmented components of their global production chains has important implications for the strategies of states seeking to attract transnational corporate participation with their economies. ${ }^{52}$ Moreover, the growing market dominance of the largest transnational corporations has accompanied a corresponding and significant rise in their political influence over the regulatory space..$^{53}$

There is also a notable geographical distribution of home states. Overwhelmingly, the majority of top transnational corporations are headquartered in developed countries, leading UNCTAD in 2018 to report that, “... if trade is nurturing growing concentration and corporate rents, these disproportionately benefit Northern investors" ${ }^{54}$ For example, the top 25 non-financial transnational corporations ranked according to foreign assets in 2018 were incorporated in the United Kingdom, Japan, France, Germany, United States, Belgium, Hong Kong/China, Italy, Spain and Switzerland. ${ }^{55}$ Foreign direct investment (FDI) is another important measure of the activity of transnational corporations in foreign markets, as it measures the productive activities of a corporation in any nation other than the home state and where the investor has an effective voice in those activities. ${ }^{56}$ While global FDI has fallen somewhat in recent years, flows to developing countries have remained stable and

50 UNCTAD, World Investment Report 2013-Global Value Chains: Investment and Trade for Development (UNCTAD 2013) 134-40.

51 UNCTAD, Trade and Development Report 2018: Power, Platforms and Free Trade Delusion (UNCTAD 2018) 35-61.

52 UNCTAD 2013 (fn 50), 140-47.

53 UNCTAD 2018 (fn 51), 42-43.

54 UNCTAD 2018, 58.

55 UNCTAD, “Annex Table 19: The World's Top 100 Non-Financial MNEs, Ranked by Foreign Assets" https://worldinvestmentreport.unctad.org/annex-tables/ (accessed 30 April 2021). Ownership of foreign assets is only one possible measure of size. Others include annual revenue, revenue compared to state gross domestic product and employment. These different measures however still produce a remarkably consistent list of the largest transnational corporations: Roach, "A Primer on Multinational Corporations" (2005) (fn 49) 25-26.

56 Roach, “A Primer on Multinational Corporations" (2005) (fn 49) 25. 
in the region of US\$706 billion in $2018 .{ }^{57}$ The global aggregate of FDI inflows were reported in 1980 to be approximately US $\$ 50$ billion. $^{58}$

Attracting FDI is important for the economies of developing countries. In 2003 Oxfam America reported that:

Foreign direct investment (FDI) ... has become such an important part of global development strategies that it has replaced foreign aid as the main source of external capital for many developing countries. Today, FDI amounts to about 60 percent of the international capital flowing into developing countries each year and is nearly ten times larger than official development assistance. In contrast, in the late 1980s, the amounts of annual aid and FDI in developing countries were roughly the same. ${ }^{59}$

FDI has slipped since the global financial crises, particularly to and from developed countries, as transnational corporations hold onto their "record levels of cash holdings" rather than risk investment. ${ }^{60}$ However there has been less shrinkage in the developing world, which now claims over half of all FDI inflows, and FDI to structurally weak economies has hit a record high. ${ }^{61}$ The drive to attract FDI as a fundamental means of securing economic growth and to access much needed technology in the Global South has significant policy implications that bear on the nature of the prevailing corporate governance gap of recent decades.

\section{The Accountability Gap}

Corporations are multinational while legal systems are still largely national, creating a disconnect between international corporate structures and the law. A review of the history and focus of the transnational enterprise demonstrates that the multi-layered, multinational division of labor and responsibility of the modern corporation, its single-minded focus on economic gain, and its economic and political power all

\footnotetext{
57 UNCTAD, World Investment Report 2019: Special Economic Zones (UNCTAD 2019) 3 .

58 Calliess, "Introduction: Transnational Corporations Revisited" (2011) (fn 25) 606. Roach estimates that the growth of FDI outflows in current prices saw an absolute increase of more than 2,100 percent during the period of 1982-2001: Roach, "A Primer on Multinational Corporations" (2005) (fn 49) 25.

59 Oxfam America and Make Trade Fair, "Investing in Destruction: The Impact of a WTO Investment Agreement on Extractive Industries in Developing Countries" Oxfam America Briefing Paper (June 2003) 6. See also UNCTAD, World Investment Report 2007-Transnational Corporations, Extractive Industries and Development (UNCTAD 2007) iii, noting that FDI represents "the largest share of capital flows to developing countries", with the most notable growth in FDI to developing countries richly endowed with natural resources and in the extractive industries generally.

60 UNCTAD 2018 (fn 51), 2-3.

61 UNCTAD 2018.
} 
render multinational corporations a difficult regulatory target. Multinational corporations have long outgrown the legal structures to govern them, reaching a level of transnationality and economic power that exceeds domestic law's ability to impose basic human rights norms. ${ }^{62}$

The reasons why the current regulatory environment is, as the SRSG puts it, permissive of unsanctioned transnational corporate human rights violations are well rehearsed. The human rights accountability challenge is understood to arise particularly from the state-centrism of international human rights law and the presence of powerful disincentives and barriers that militate against states unilaterally regulating transnational corporate activities. ${ }^{63}$ These disincentives and barriers are particularly acute for developing countries and for states with weak governance or in situations of conflict. ${ }^{64}$

Primarily, it is states that have duties under international law. It is therefore states that have both the legal authority and, in some instances, the obligation to regulate corporate activities within their jurisdictions that may impact adversely on human rights. ${ }^{65}$ A state's obligation to regulate the human rights impacts of companies has at least two bases. First, a state will be attributed international responsibility for the conduct of a corporation that constitutes an "internationally wrongful act", whether it occurs at home or abroad, where that corporation was exercising elements of governmental authority or was acting under government control. ${ }^{66}$ This principle therefore only applies to a limited set of situations. A broader obligation arises by virtue of a state's duty to protect human rights within its territories, an obligation contained in various international human rights instruments and in customary international

62 Beth Stephens, "The Amorality of Profit: Transnational Corporations and Human Rights" (2002) 20 Berk J Intl L 45, 54.

63 The dynamics of the governance gap have been articulated by a number of human rights law scholars and organisations, including: Joseph, "Taming the Leviathans: Multinational Enterprises and Human Right" (1999) (fn 6) 175-83; Olivier De Schutter, "The Accountability of Multinationals for Human Rights Violations in European Law" in Philip Alston (ed), Non-State Actors and Human Rights (OUP 2005) pp 230-40; and Ratner, "Corporations and Human Rights: A Theory of Legal Responsibility" (2001) (fn 40) 461-75; Framework (fn 2), [3]-[4] and [11]-[16].

${ }^{64}$ Framework (fn 2), [36] (on developing countries) and [47]-[49] (on conflict zones).

${ }_{65}$ The notion of jurisdiction is complex. For an explanation of its purchase in respect of state duties under human rights law see Sarah Joseph and Adam Fletcher, "Scope of Application" in Daniel Moeckli et al (eds), International Human Rights Law, 2nd edn (OUP 2014).

66 "Draft Articles on Responsibility of States for Internationally Wrongful Acts, with Commentaries", Report of the International Law Commission on the Work of Its Fifty-Third Session (3 August 2001) UN Doc A/56/10, arts 5 and 8. 
law. The duty to protect incorporates a positive obligation to protect against human rights abuses by private actors. States must exercise due diligence to prevent, punish, investigate or redress the harm caused by private persons. Failure to do so results in the state breaching its own human rights duties. ${ }^{67}$ It is notable, however, that promoting transnational corporate regulation through the state's own human rights accountability under international law has been an under-utilised accountability mechanism to date. ${ }^{68}$

The "horizontal" application of international human rights law described above places the responsibility for the regulation of corporations on the state that is hosting the corporate group's physical operations (the host state). ${ }^{69}$ This is because there are only limited circumstances in which international human rights law extends a state's human rights obligations beyond its territorial borders. ${ }^{70}$ So, while often called for, ${ }^{71}$ it is unlikely that, as a general rule, the

67 Joseph and Fletcher, "Scope of Application" (2014) (fn 65) 123-125. For a discussion of cases where states have been found to have breached their human rights obligations by unduly favouring corporate interests, see Sarah Joseph, "Liability of Multinational Corporations" in Malcolm Langford (ed), Social Rights Jurisprudence: Emerging Trends in International and Comparative Law (CUP 2008) pp 615-617.

${ }_{68}$ Sarah Joseph, "An Overview of the Human Rights Accountability of Multinational Enterprises" in Menno T. Kamminga and Saman Zia-Zarifi (eds), Liability of Multinational Corporations under International Law (Kluwer Law 2000) p 78. See also UNHRC, "Report of the Special Representative of the Secretary-General (SRSG) on the Issue of Human Rights and Transnational Corporations and Other Business Enterprises" (9 February 2007) UN Doc A/HRC/4/035 [17] and [86], noting that of a sample survey of states, few had "internalised the full meaning of the state duty to protect".

69 Some argue that the logic of international human rights law necessitates, by implication, that third parties are directly obliged to comply with human rights. See, e.g. David Bilchitz, "A Chasm Between 'Is' and 'Ought'? A critique of the Normative Foundations of the SRSG's Framework and Guiding Principles" in Surya Deva and David Bilchitz (eds), Human Rights Obligations of Business: Beyond the Corporate Responsibility to Protect? (CUP 2014) pp 110-112.

${ }_{70}$ These circumstances are further circumscribed when considering the duty to protect, as opposed to the duty to respect, human rights. On the circumstances in which 'jurisdiction' in international human rights law may extend beyond the states' territorial limits, see Joseph and Fletcher, "Scope of Application" (2014) (fn 65) 129-38.

71 See, e.g. Maastricht Principles on Extraterritorial Obligations of States in the Area of Economic, Cultural and Social Rights (ETO Consortium 2011) Principle 24. 
concept of horizontality extends to oblige home states to regulate the conduct of their corporate nationals abroad, ${ }^{72}$ although they are permitted to do so. ${ }^{73}$

The current system of leaving transnational corporate human rights regulation almost exclusively to host states has, however, proven inadequate. This is particularly true in respect of corporate activities in the developing world. A very real practical disincentive to host state regulation arises by virtue of the dependence of developing countries upon FDI, described above. De Schutter describes the effect of this dependency as giving rise to a "prisoner's dilemma". ${ }^{74}$ In a global economic context, where access to foreign corporate investment is fundamental to economic growth, developing states necessarily compete for foreign investment by offering local conditions attractive to investors. ${ }^{75}$ Such competition can lead to a process of reduced labour, tax, environmental and other regulation or, at a minimum, a failure to improve lax regulation over time, a phenomenon known as the "race to the bottom". ${ }^{76}$ As De Schutter argues, while developing states may collectively have an interest in corporate activity within their territories meeting minimum standards, individually such states are de-incentivised from imposing regulatory burdens on corporate activity for fear that foreign investors will simply look elsewhere. ${ }^{77}$ This push towards laxer standards is further compounded by the concurrent competition between developing and developed nations for FDI, with lesser regulation and the associated lower production costs seen by developing

72 Joseph and Fletcher, "Scope of Application" (2014) (fn 65) 134-136. For a discussion of the circumstances in which states are obliged to regulate businesses in their extraterritorial conduct, see Daniel Augenstein and David Kinley, "When Human Rights 'Responsibilities' become 'Duties': the Extraterritorial Obligations of States that Bind Corporations" in Surya Deva and David Bilchitz (eds), Human Rights Obligations of Business: Beyond the Corporate Responsibility to Protect? (CUP 2014) p 271.

73 It is generally recognised in international law that states can exercise extraterritorial jurisdiction over wrongs committed by their nationals abroad: Joseph, "Taming the Leviathans: Multinational Enterprises and Human Right" (1999) (fn 6) 177.

74 De Schutter, "The Accountability of Multinationals for Human Rights Violations in European Law" (2005) (fn 63) 238.

75 De Schutter, "The Accountability of Multinationals for Human Rights Violations in European Law" (2005).

${ }_{76}$ For an analytic investigation of the dynamic of the "race to the bottom", see Debora Spar and David Yoffie, "Multinational Enterprises and the Prospects for Justice" (1999) 52(2) J.Int'l Aff. 557.

77 De Schutter, "The Accountability of Multinationals for Human Rights Violations in European Law" (2005) (fn 63) p 238. He notes that this is also true even of fixed resource industries where companies know that their expertise is fundamental to the state in order to commercially exploit the resource. 
countries as their competitive advantage. ${ }^{78}$ Furthermore, the economic power of some transnational corporations can translate into de facto corporate political power pressing against regulation unfavourable to corporate interests. ${ }^{79}$ Revelations through leaked US embassy cables ${ }^{80}$ and through insider reports ${ }^{81}$ illustrate the potential political clout of corporations that are crucial to states in their exploitation of local resources. As a result of these kinds of dynamics, commentators have argued that by acting collectively, developing states maximise their ability to control the flow and direction of FDI towards local interests. $^{82}$

These systemic pressures towards under-regulation can be cemented into legal limitations placed on host states in respect of their treatment of foreign investors through bilateral investment treaties (BITs) and host government agreements (HGAs). These legally binding state-state and investor-state contracts are a means by which host states offer protection to foreign investors, ostensibly to encourage foreign investment in the state. ${ }^{83}$ Among other things, these agreements can incorporate "stabilisation clauses" that either freeze the law of the host state for the duration of a project, which in some industries can be up to 50 years,${ }^{84}$ or oblige the state to compensate the investor for any costs incurred by complying with new law. ${ }^{85}$ Such clauses can substantially limit the

78 De Schutter, "The Accountability of Multinationals for Human Rights Violations in European Law" (2005) 239.

79 Joseph, "An Overview of the Human Rights Accountability of Multinational Enterprises" (2000) p 78; David Rothkopf, Power, Inc: The Epic Rivalry between Big Business and Government - and the Reckoning that Lies Ahead (Viking 2012).

80 See, e.g. Tim Webb, "WikiLeaks Cables: Azerbaijan Complains of BP Clout in Country", The Guardian (online, 16 December 2010) http://www.theguardian.com/ world/2010/dec/15/wikileaks-cables-azerbaijan-bp-oil (accessed 30 April 2021).

${ }_{81}$ See, e.g. Steve Coll, Private Empire: Exxon Mobil and American Power (Penguin Press 2012).

${ }_{82}$ Surya Deva, "The Sangam of Foreign Investment, Multinational Corporations and Human Rights: An Indian Perspective for a Developing Asia" [2004] Sing JLS 305.

83 For a brief history of BITs, see Srividya Jandhyala et al, "Three Waves of BITs: The Global Diffusion of Foreign Investment Policy" (2011) 55(6) J.Conflict Resol 1047. At the height of their popularity in 2005, nearly 2,500 BITs were in existence: UNCTAD, World Investment Report 2006-FDI from Transitional and Developing Economies (UNCTAD 2006) xix.

84 Framework, [35].

85 For a discussion of forms of stabilisation clauses, see Andrea Shemberg, Stabilization Clauses and Human Rights: A Research Project Conducted for IFC and the United Nations Special Representative of the Secretary-General on Business and Human Rights (International Finance Commission 2009) 4-9. On the legal status and effect of BITs, see Lorenzo Cotula, "Reconciling Regulatory Stability and Evolution of Environmental Standards in Investment Contracts: Towards a Rethink of Stabilization Clauses" (2008) 1(2) J World Energy L \& Business 158, 159-67. 
policy space of host states to apply social or environmental laws and thereby constrain government efforts to achieve human rights goals. ${ }^{86}$ Amnesty International, for example, have previously pointed to the implications of private investment agreements that apply to particular oil extraction and transportation projects in Chad and Cameroon that hamper the response options of those governments to human rights concerns and challenges proximate to the projects. Both countries have a history of a strong correlation between conflict and the extractive industries. ${ }^{87}$

The conditionalities of investment agreements are given bite by provisions that entitle foreign investors to bring international arbitral claims against governments for violations of the contract. Notably, stabilisation clauses that particularly constrain host state regulatory capacity appear overwhelming in agreements signed with non-OECD countries relative to those involving OECD countries. ${ }^{88}$ Further, it is developing countries that have been the subjects of the vast majority of international arbitral claims. ${ }^{89}$ Unsurprisingly, some developing states are now openly critical of the conditions of existing investment agreements, particularly those entered into in early periods of decolonisation and when technical expertise in the newly independent states was limited. ${ }^{90}$

Investment law is only one of the ways in which international economic governance can shrink the human rights policy space of states, with a differential impact on the Global South. This outcome has also been linked to international trade law. ${ }^{91}$ The effects of these legal frameworks has led some to critique the

86 See, e.g. Sheldon Leader, "Human Rights, Risks, and New Strategies for Global Investment" (2006) 9 J.Intl Econ L 657; Framework [33]-[38]; Shemberg, Stabilization Clauses and Human Rights (2009) (fn 85) 37; Cotula, "Reconciling Regulatory Stability and Evolution of Environmental Standards in Investment Contracts: Towards a Rethink of Stabilization Clauses" (2008) (fn 85) 158-79.

87 Amnesty International, Contracting Out of Human Rights: The Chad-Cameroon Pipeline Project (Amnesty International UK 2005) pp 15-17.

${ }_{88}$ Shemberg, Stabilization Clauses and Human Rights (2009) (fn 85) ix-x, 17-33, 37.

89 Lauge N. Poulsen and Emma Aisbett, "When the Claim Hits: Bounded Rationality and Bilateral Investment Treaties" (2013) 65(2) Wld.Pol. 273, 275.

90 See, e.g. Kizito Makoye, "Tanzania Committee Says Billions Lost to Corporate Tax Evasion", Thomson Reuters Foundation (online, 14 October 2013) http://www .trust.org/item/20131014094858-3frio (accessed 30 April 2021), reporting comments of Zitto Kabwe, Chairman of the Parliamentary Committee on Public Accounts, in Tanzania. For hypotheses as to the dynamics of decision making by developing countries in respect of BITs, see Poulsen and Aisbett, "When the Claim Hits: Bounded Rationality and Bilateral Investment Treaties" (2013) (fn 89) 273-313.

91 Sarah Joseph, "Trade Law and Investment Law" in Dinah Shelton (ed), The Oxford Handbook of International Human Rights Law (OUP 2013) pp 847-849. 
notion that big business has today "transcended" or "outgrown" the state, state power and the current international regulatory framework. Rather than resulting from a lack of law, transnational corporate insulation from human rights accountability is instead viewed as a function of law..$^{92}$ According to this view, impunity is constructed by biases inherent in existing law and policy that facilitate private investment and private corporate rights without corresponding recognition of public human rights interests. As a corporate and securities law expert, Stevelman, notes, what is often forgotten is that the global corporation (and indeed the domestic corporation) are inventions of the law. ${ }^{93}$ She states, "[t]he invention of this kind of corporation is a story of legal invention (affirmative rule-making) and legal destruction (i.e. systematic deregulation)". ${ }^{44}$ Third world approaches to international law scholarship likewise illustrate how the promotion and protection of particular interests, in this case the economic interests of the Global North and the disadvantage of the Global South, are endemic to the international legal regime. ${ }^{95}$ This includes historical studies that link the development of particular international legal principles, such as state succession, acquired rights, consent and contract, to colonialism and to the goal of opening southern markets for economic exploitation by northern states. ${ }^{96}$ Adopting the Marxist "commodity form theory of law", Baars argues that the international legal system is itself a vehicle of capitalist growth and exploitation and thus is deeply designed towards, rather than to curb, capital-

92 See, e.g. Daniel Aguirre, "Corporate Liability for Economic, Social and Cultural Rights Revisited: The Failure of International Cooperation" (2011) 42 Cal.W.Int'l L.J 123; Penelope Simons, "International Law's Invisible Hand and the Future of Corporate Accountability for Violations of Human Rights" (2012) 3(1) JHRE 5. See also Doreen Lustig, Veiled Power: International Law and the Private Corporation 1886-1981 (OUP, 2021).

93 Faith Stevelman, "Global Finance, Multinationals and Human Rights: With Commentary on Backer's Critique of the 2008 Report by John Ruggie" (2011) 9(1) Santa Clara J Intl L 107. See also Peter Muchlinski, "The Changing Face of Transnational Business Governance: Private Corporate Law Liability and Accountability of Transnational Groups in a Post Financial Crisis World" (2011) 18(2) Ind.J.Global Legal Studies 665, 666-84.

94 Stevelman, "Global Finance, Multinationals and Human Rights: With Commentary on Backer's Critique of the 2008 Report by John Ruggie" (2011) (fn 93) 107 and 123.

95 Simons, "International Law's Invisible Hand and the Future of Corporate Accountability for Violations of Human Rights" (2012) (fn 92) 19-29.

96 Simons, "International Law's Invisible Hand and the Future of Corporate Accountability for Violations of Human Rights" (2012) 20-22 (describing the work of Antony Anghie). 
ism's (and thus corporate) excesses ${ }^{97}$ What these critiques have in common is that they point to a problem not simply of a lack of law but of the kind of global and domestic law that has evolved to facilitate global trade and investment. Points of difference between such critiques lie in the degree to which law could thus ever be a solution to this problem.

Principles of company law also problematise corporate human rights accountability for harms arising from transnational corporate operations..$^{98}$ The legal arrangements of transnational corporate groups have developed to maximise the immunity of parent corporations from risks associated with their global operations. ${ }^{99}$ Tiers of distinct corporate entities insulate the parent company from liability through the doctrines of separate corporate juridical personality ${ }^{100}$ and limited liability ${ }^{101}$ in corporation law. Even where there is effective local regulation, the more appropriate target for litigation or prosecution may be a parent corporation, which may be an impractical target for the host state. ${ }^{102}$ Targeting subsidiary companies that are present in the host state may be of limited value as subsidiaries may be under-capitalised and second- or third-tier companies can be dissolved in order to avoid liability. ${ }^{103}$

97 Grietje Baars, The Corporation, Law and Capitalism: A Radical Perspective on the Role of Law in the Global Political Economy (Brill 2019) pp 76-131.

98 See, e.g. Philip I. Blumberg, "Accountability of Multinational Corporations: The Barriers Presented by Concepts of the Corporate Juridical Entity" (2001) 24(3) Hastings Int'1 \& Comp.L.Rev 297; Peter Muchlinski, "Limited Liability and Multinational Enterprises: A Case for Reform" (2010) 34(5) Camb.J.Econ. 915; Kiarie Mwaura, "Internalization of Costs to Corporate Groups: Part-whole Relationships, Human Rights Norms and the Futility of the Corporate Veil" (2012) 11(1) Can.J.Inter. Bus.L.\& Pol'y 85, discussing the ways in which entity law undermines human rights by incentivising transnational corporate disregard for human rights.

99 Jonathan Clough, "Not-so-innocents Abroad: Corporate Criminal Liability for Human Rights Abuses" (2005) 11(1) AJHR 1, 9.

100 Separate corporate juridical liability refers to the rule that "a corporation and its shareholders are separate juridical entities and ... the corporation's rights and liabilities are separate and distinct from the rights and liabilities of its shareholders": Blumberg, "Accountability of Multinational Corporations: The Barriers Presented by Concepts of the Corporate Juridical Entity" (2001) (fn 98) 301.

101 The principle of limited liability "limits the liability of shareholders, including corporate shareholders, to the unpaid amount of their investment": Clough, "Not-so-innocents Abroad: Corporate Criminal Liability for Human Rights Abuses" (2005) (fn 99) 9. For a discussion of the development of this principle, see Blumberg, "Accountability of Multinational Corporations: The Barriers Presented by Concepts of the Corporate Juridical Entity" (2001) (fn 98).

102 Clough, "Not-so-innocents Abroad: Corporate Criminal Liability for Human Rights Abuses" (2005) (fn 99) 9-11.

103 Clough, "Not-so-innocents Abroad: Corporate Criminal Liability for Human Rights Abuses" (2005). 
In any event, penetrating the formally disaggregated corporate entities within multinational enterprises so that the actions of a subsidiary can be attributed to the parent company for the purpose of determining jurisdiction and imposing responsibility (known as piercing the corporate veil) can be extremely difficult. Corporate law allows for only very limited circumstances where the court will look behind the legal form. ${ }^{104}$ Increasingly, there are calls for an enterprise approach to be adopted in human rights litigation in the interest of substantive justice. This means courts would focus more on the reality of economic integration within a corporate group in making decisions in such claims, rather than to strictly upholding distinct legal forms. ${ }^{105}$ However, in the practices of domestic courts, the entity approach of corporate law orthodoxy still prevails. ${ }^{106}$ Even where a claim against the parent is feasible under principles of corporate law, it may be impractical for a host state to attempt to prosecute a parent corporation due to its lack of presence in the host jurisdiction. ${ }^{107}$ Interstate cooperation and coordination are needed to realise the justice aims of domestic legal responses. ${ }^{108}$

Beyond these legal constraints, host states may be unwilling or unable to address human rights abuses due to extra-legal factors internal to the state, a situation sometimes referred to by the concept of "weak governance zones". ${ }^{109}$ Unwillingness might arise where the state is the prime violator or

104 Blumberg, "Accountability of Multinational Corporations: The Barriers Presented by Concepts of the Corporate Juridical Entity" (2001) (fn 98) 304-311; Anil Yilmaz Vastardis and Rachel Chambers, 'Overcoming the Corporate Veil Challenge: Could Investment Law Inspire the Proposed Business and Human Rights Treaty?' (2018) 67 ICLQ 389, 393-97.

105 See, e.g. Blumberg, "Accountability of Multinational Corporations: The Barriers Presented by Concepts of the Corporate Juridical Entity" (2001) (fn 98) 311-316; Muchlinski, "Limited Liability and Multinational Enterprises: A Case for Reform" (2010) (fn 98) 919-25; Mwaura, "Internalization of Costs to Corporate Groups: Part-whole Relationships, Human Rights Norms and the Futility of the Corporate Veil" (2012) (fn 98) 102-105.

106 Muchlinski, "Limited Liability and Multinational Enterprises: A Case for Reform" (2010) (fn 98) 922.

107 Clough (n 99) 10. Mwaura, "Internalization of Costs to Corporate Groups: Part-whole Relationships, Human Rights Norms and the Futility of the Corporate Veil" (2012) (fn 98) 105.

108 Mwaura, "Internalization of Costs to Corporate Groups: Part-whole Relationships, Human Rights Norms and the Futility of the Corporate Veil" (2012) (fn 98) 105-10.

109 UNHRC, "Report of the Special Representative of the Secretary-General on the Issue of Human Rights and Transnational Corporations and Other Business Enterprises-Addendum: Corporate Responsibility under International Law and Issues in Extraterritorial Regulation: Summary of Legal Workshop" (15 February 2007) UN Doc A/HRC/4/35/Add.2 [22]-[25]. 
otherwise authorises, supports or acquiesces to the violations. ${ }^{110}$ This can be true of a wide range of human rights, for example discriminatory labour laws and laws against unionisation, but it has a greater import in the field of international crimes. The scale and the elements of international crimes mean that such offences regularly involve the "help and assistance, or the connivance and acquiescence, of national authorities". ${ }^{111}$ This creates the very real risk that investigation and prosecution of harms will not occur or, where they do, that justice efforts may not be genuine. Apart from an unwillingness to genuinely investigate cases of gross human rights abuses, the commission of international crimes may alternatively reflect the loss of control by government authorities to impose order and distribute justice. As a result, investigations and punishments of offenders may be impossible. In this sense, there can be said to be dual sources of corporate impunity for international crimes: those that flow from the governance gap that exists in respect of transnational corporate harms, and those that inhere to international crimes.

In response to these challenges, victim groups have attempted "foreign direct liability" suits to access justice. These are civil claims against parent companies of a multinational group brought in the civil courts of developed countries, generally the parent company's home state, that test the extraterritorial limits of civil litigation rules. ${ }^{12}$ However, practical and legal challenges created by the complexity of modern corporate structures and activity can make access to justice via this route also difficult. Challenges include attributing the wrong of a subsidiary to a parent company (the corporate veil challenge created by formal legal separation of companies within a corporate group); demonstrating the direct liability of the parent corporation to persons impacted by a subsidiary's operations; ${ }^{113}$ establishing permissive grounds for courts to exercise extraterritorial jurisdiction; meeting admissibility tests such as forum non conveniens that demand, to varying degrees, that a court be satisfied there is no better country in which the claim might be heard; obtaining international cooperation as needed to progress extraterritorial claims; victims having the

110 De Schutter, "The Accountability of Multinationals for Human Rights Violations in European Law" (2005) (fn 63) 237-38.

111 Antonio Cassese, "The Statute of the International Criminal Court: Some Preliminary Reflections" (1999) 10(1) EJIL 144, 159.

112 Muchlinski, "The Changing Face of Transnational Business Governance: Private Corporate Law Liability and Accountability of Transnational Groups in a Post Financial Crisis World" (2011) (fn 93) 685-90. The term "foreign direct liability" is intended to reflect the flip side of foreign direct investment.

113 In that respect, there have been two significant UK cases in recent years that have elaborated the range of circumstances that might give rise to a duty of care on the part of a parent company to persons harmed by activities of a subsidiary: Lungowe $v$ Vedanta Resources Plc [2019] UKSC 20; Okpabi v Royal Dutch Shell Plc [2021] UKSC 3. 
financial capacity to obtain legal advice and to litigate; establishing standing to sue; and the existence of a raft of disincentives for lawyers to represent claimants in such cases. ${ }^{114}$ Additionally, the adjudication of corporate activity that has primarily occurred in the territory of another state can raise the ire of other states as a perceived intrusion on state sovereignty, creating potential for political pressures against claims proceeding. ${ }^{15}$

One way to increase the legal accountability of corporations in their global operations is via state regulatory measures directed towards specific aspects of corporate activity. Often catalysed by international efforts and agreements, some examples do now exist. These include, for example, suppression treaties that require states to create corporate liability offences for bribery and corruption. ${ }^{116}$ Likewise, home state laws in respect of international crimes that extend to corporations are a major innovation that may have the potential to increase corporate accountability for involvement in atrocity, if used. There are certainly benefits to home state regulation. ${ }^{117}$ Home states are more likely to be developed countries and to have relative power parity with corporations, ${ }^{118}$ as well as being sufficiently resourced to handle complex corporate cases. As economic beneficiaries of extraterritorial corporate activity, home states arguably have a corresponding moral duty to regulate that corporate behaviour. Access to legal aid, legal expertise and class action tools may also be an advantage of pursuing litigation in some states over others. However, unilateral home state regulation has been criticised for creating a commercial disadvantage for

114 UNHRC, "Report of the Special Representative of the Secretary-General on the Issue of Human Rights and Transnational Corporations and Other Business Enterprises" (9 April 2010) UN Doc A/HRC/14/27 [103]-[113]; Richard Meeran, "Tort Litigation against Multinational Corporations for Violations of Human Rights: An Overview of the Position outside the United States" (2011) 3 City U of Hong Kong L Rev 1.

115 Joanna Kyriakakis, "Prosecuting Corporations for International Crimes: The Role for Domestic Criminal Law" in Larry May and Zachary Hoskins (eds), International Criminal Law and Philosophy (CUP 2010) pp 131-135.

116 See, e.g. OECD Convention on Combating Bribery of Foreign Public Officials in International Business Transactions (entered into force 15 February 1997, opened for signature 17 December 1997) 37 ILM 1, arts 2, 3(2) and 4.

117 For a discussion of policy justifications for holding home states liable for the conduct of transnational corporations abroad, see Muthucumaraswamy Sornarajah, "Linking State Responsibility for Certain Harms Caused by Corporate Nationals Abroad to Civil Recourse in the Legal Systems of Home States" in Craig Scott (ed), Torture as a Tort (Hart Publishing 2001) p 491; De Schutter, "The Accountability of Multinationals for Human Rights Violations in European Law" (2005) (fn 63) 235-36.

118 Joseph, "An Overview of the Human Rights Accountability of Multinational Enterprises" (2000) (fn 68) 84. 
the state's corporate nationals on the global stage. ${ }^{119}$ This kind of argument was successfully used in an industry campaign against Bill C-300 that MP John McKay attempted to introduce in Canada in 2009. A relatively modest proposition, the Bill would have enabled Canadian government authorities to investigate complaints against Canadian resource companies operating abroad and to withhold public funds from companies found to have breached certain environmental and human rights standards. ${ }^{120}$ The Bill was motivated by reports of serious human rights violations related to Canadian resource operations abroad and the impact these were having upon the reputation of Canada internationally. ${ }^{121}$ It was narrowly defeated following a significant opposition campaign undertaken by the mining lobby. ${ }^{122}$

For his part, the SRSG advocated home state regulation to reduce accountability gaps. ${ }^{123}$ Yet, he himself notes that states exercising extraterritorial jurisdiction tend to be, and are perceived to be, more reasonable where the exercise of power forms part of multilateral measures and where there is a reasonable degree of international consensus on the wrongfulness of the activity being regulated. Consensus is achieved through states agreeing to common standards and enforcement mechanisms. ${ }^{124}$ The development of international anti-corruption and anti-bribery treaties illustrate the way in which formalised international cooperation both grows out of and cements individual state efforts

119 Joseph, "Taming the Leviathans: Multinational Enterprises and Human Right" (1999) (fn 6) 181. Stakeholders at an SRSG special workshops on questions of extraterritorial home state regulation also noted that both host and home states may worry about "being competitively disadvantaged if they were too strict on business and that more should be done at the international level to address such concerns": UNHRC, "Report of the Special Representative of the Secretary-General on the Issue of Human Rights and Transnational Corporations and Other Business Enterprises-Addendum: Summary of Five Multi-Stakeholder Consultations" (23 April 2008) UN Doc A/ HRC/8/5/Add.1 [2].

120 Bill C-300, An Act Respecting Corporate Accountability for the Activities of Mining, Oil or Gas in Developing Countries, 2nd Session, 40th Parl, 2009 (Can).

121 John McKay, "John McKay's Speech Moving 3rd Reading of C-300" (Hon. John McKay PC, MP, 20 September 2010).

122 Simons, "International Law's Invisible Hand and the Future of Corporate Accountability for Violations of Human Rights" (2012) (fn 92) 31.

123 UNHRC, "Guiding Principles on Business and Human Rights: Implementing the United Nations 'Protect, Respect and Remedy' Framework” (21 March 2011) UN Doc A/HRC/17/31, Principle 2 and Commentary (hereafter "UNHRC Guiding Principles").

124 UNHRC, "Report of the Special Representative of the Secretary-General on the Issue of Human Rights and Transnational Corporations and Other Business Enterprises" (19 August 2010) UN Doc A/65/310 [25]-[27]. For a discussion as to why extraterritorial jurisdiction is more legitimate and effective when applied pursuant to a multilateral agreement rather than unilaterally, see Austen L. Parrish, "Kiobel, Unilateralism, and the Retreat from Extraterritoriality" (2013) 28 Maryland J.Int'l L 208. 
to tackle harmful corporate practices that create regulatory challenges due to cross-border dimensions. ${ }^{125}$ And yet, to the dismay of some, the SRSG advocated against any immediate efforts towards a binding treaty on the subject of business and human rights that might further facilitate legal coordination among states and the clarification of clear standards. ${ }^{126}$ For many, the SRSG's ultimate framework for going forward rings hollow as it failed to propose any collective formal legal mechanism to address the challenges he so clearly identified. Instead, his framework seeks to encourage states and business to do what they have so far failed to do, namely to take rights seriously. However, the exceptional treatment of international criminal law, as a source of extant binding legal obligation on corporations directly, is an outlier in that regard.

The following section sets out some of the key international efforts on business and human rights, focussing in particular upon the SRSG framework. It argues that the special emphasis given to international crimes in the SRSG framework, as the only human rights obligations currently legally binding directly on corporations, and his confidence in international criminal law as a mechanism of formal accountability, is both overly optimistic and prospectively catalytic, as it may create the drive toward the outcome the SRSG already considers present, which is the application of international criminal law to global business.

\section{International Responses: The SRSG Framework and Its Ramifications for International Criminal Law}

Initiatives at an international level to address the challenge of business and human rights have to date been dominated by the ethos of corporate social responsibility or CSR. CSR is a management concept whereby businesses are encouraged to take into account social and environmental impacts in their decision making, operations and interactions with stakeholders, rather than being solely guided by immediate economic benefits and costs. Generally speaking, it is associated with processes voluntarily undertaken by companies and aimed

125 On the development of the anti-corruption treaties and how this example pertains to the current business and human rights debate, see Anita Ramasastry, "Closing the Governance Gap in the Business and Human Rights Arena: Lessons from the Anti-Corruption Movement" in Surya Deva and David Bilchitz (eds), Human Rights Obligations of Business: Beyond the Corporate Responsibility to Protect? (CUP 2014) p 162.

126 For an outline of the SRSG's position on a treaty and his public debate with non-government organisations on this subject, see Ramasastry, "Closing the Governance Gap in the Business and Human Rights Arena: Lessons from the Anti-Corruption Movement" (2014) 164-172. 
at internalising the consideration of these wider impacts at various governance levels, on the basis that to do so is a strategic business management practice that will benefit the company, as well as the communities they interact with. ${ }^{127}$ It is thus a form of corporate ethics. ${ }^{128}$

Consistent with this notion, international initiatives to address the governance gap in global business and human rights have to date been overwhelmingly "soft law" in nature. Soft law, though a vague concept, encompasses a range of international, multilateral and corporate initiatives that promote the development and the (generally) voluntary integration of international human rights principles into business conduct but that fall short of creating direct legal ramifications for failing to do so. ${ }^{129}$ They are initiatives born of the intent to create compliance pull outside of a formally binding legal mechanism. ${ }^{130}$ Significant examples are the International Labour Organization Tripartite Declaration of Principles Concerning Multinational Enterprises and Social Policy, ${ }^{131}$ the UN Global Compact, ${ }^{132}$ the Organisation for Economic Co-operation and Development (OECD) Guidelines for Multinational Enterprises ${ }^{133}$ and, in the extractive industries, the Voluntary Principles on Security and Human Rights. ${ }^{134}$ Individual corporate codes of conduct are also a crucial part of the landscape of soft law instruments and have proliferated since the 1970s onwards. While some of these measures contain mechanisms by which corporations can be asked to account for their conduct, they do not create formal legal ramifications where a breach of standard is positively identified.

As a result of the predominance of soft law, as opposed to binding hard law, in the international regulatory framework on business and human rights, a persistent question is the relative effectiveness of each approach in the global

127 For a discussion of definitional debates, see Bryan Horrigan, Corporate Social Responsibility in the 21st Century: Debates, Models and Practices across Government, Law and Business (Edward Elgar Publishing 2010) Ch 2.

128 Jennifer A. Zerk, Multinationals and Corporate Social Responsibility (CUP 2006) p 32.

129 Justine Nolan, "The Corporate Responsibility to Respect Human Rights: Soft Law or Not Law?" in Surya Deva and David Bilchitz (eds), Human Rights Obligations of Business: Beyond the Corporate Responsibility to Protect? (CUP 2014) pp 139-143.

130 Nolan, "The Corporate Responsibility to Respect Human Rights: Soft Law or Not Law?" (2014) 144-45.

131 International Labour Organization (ILO), "Tripartite Declaration of Principles concerning Multinational Enterprises and Social Policy" (Fifth edn, ILO 2017).

132 UN Global Compact (2000) (amended June 2004) http://www.unglobalcompact .org/ (accessed 30 April 2021).

133 OECD, OECD Guidelines for Multinational Enterprises (OECD Publishing 2011).

134 Voluntary Principles on Security and Human Rights (2000), http://www .voluntaryprinciples.org/ (accessed 30 April 2021). 
economic context. ${ }^{135}$ Those in favour of binding legal accountability argue that non-binding voluntary measures suffer a number of weaknesses: they exclude persistent laggards that choose not to participate and that might constitute some of the worst offenders; they result in a diversity of human rights standards as determined by each particular industry or company, creating a cacophony of standards, and, further, these can fall short of expectations under international human rights law; they fail to provide comprehensive coverage, leaving areas of risk unaccounted for; ${ }^{136}$ there is a risk that initiatives will constitute a form of "whitewashing" whereby the existence of a measure provides the veneer of corporate social engagement without resulting in meaningful changes; ${ }^{137}$ and, when breached, they result in inadequate remedial or putative measures. On the other hand, there are those who argue that soft law measures have a number of strengths. These include that they are often politically more feasible, they are more efficient and effective methods by which to inculcate human rights considerations into corporate conduct, and they serve to normalise expectations of business and thus create a foundation upon which formal legal norms can then be effectively imposed. In other words, they are considered a crucial step in international processes toward formally binding laws. ${ }^{138}$

In contrast to the CSR focus of most multilateral and corporate initiatives, efforts at the UN, at least until the SRSG, were oscillating toward

135 The proposition that there is a strict dichotomy between "soft law" as non-binding and "hard law" as binding is overly simplistic. There are various means by which behavioural expectations arising from soft law mechanisms can migrate into legally binding obligations or, falling short of this, can have a strong compliance pull upon the subject of the norm. In this respect, soft law initiatives are probably best understood on a spectrum where the authority and "binding-ness" of such standards range from low to high: Nolan, "The Corporate Responsibility to Respect Human Rights: Soft Law or Not Law?" (2014) (fn 129) pp 144-145; David Kinley and Rachel Chambers, "The UN Human Rights Norms for Corporations: The Private Implications of Public International Law" (2006) 6(3) Harvard Human Rights L Rev 447, 483-90.

136 See, e.g. UNHRC, "Interim Report of the Special Representative of the Secretary-General on the Issue of Human Rights and Transnational Corporations and Other Business Enterprises" (22 February 2006) UN Doc E/CN.4/2006/97 [53]; UNHRC (fn 68) [66]-[81].

137 See, e.g. Christine Parker, "Meta-regulation: Legal Accountability for Corporate Social Responsibility" in Doreen McBarnet et al (eds), The New Corporate Accountability: Corporate Social Responsibility and the Law (CUP 2007); Christine Parker and John Howe, "Ruggie's Diplomatic Project and Its Missing Regulatory Infrastructure" in Radu Mares (ed), The UN Guiding Principles on Business and Human Rights: Foundations and Implementation (Martinus Nijhoff 2012) pp 292-301.

138 UNHRC, "Report of the Special Representative of the Secretary-General (SRSG) on the Issue of Human Rights and Transnational Corporations and Other Business Enterprises" (fn 68), [45]-[62]; Nolan, "The Corporate Responsibility to Respect Human Rights: Soft Law or Not Law?” (2014) (fn 129) 142-143. 
a non-voluntary schema, with a binding treaty addressing business and human rights considered a real, if admittedly future, prospect. ${ }^{139}$ This was most evident in activities at the UN from 1998 to 2005 . Over this time, the Sub-Commission on the Promotion and Protection of Human Rights established a working group to look at transnational corporations as a response to a surge in awareness regarding the negative impacts of economic globalisation. ${ }^{140}$ The working group developed the Norms on the Responsibilities of Transnational Corporations and Other Business Enterprises with Regard to Human Rights ("Draft Norms"), ${ }^{141}$ which set out substantive provisions as to the human rights responsibilities of transnational corporations and other business enterprises. The Draft Norms have been described by those involved in their development as soft law but of a non-voluntary nature. ${ }^{142}$ This characterisation was based upon the Draft Norms deriving their source from treaty and customary law and hence constituting a restatement of legal principles applicable to corporations. While soft law, in that it fell short of a treaty, the Draft Norms were viewed by some as a precursor towards a treaty on business and human rights. ${ }^{143}$ Until such time as a treaty was achieved, the Draft Norms would be given "teeth" through a variety of means. ${ }^{144}$ However, the Draft Norms became mired in a political stalemate, with deep polarisation among stakeholder groups emerg-

139 For a summary of UN processes on business and human rights see, Nolan, "The Corporate Responsibility to Respect Human Rights: Soft Law or Not Law?" (2014) (fn 129) 146-54; David Bilchitz and Surya Deva, "The Human Rights Obligations of Business: A Critical Framework for the Future", in Surya Deva and David Bilchitz (eds), Human Rights Obligations of Business: Beyond the Corporate Responsibility to Protect? (CUP 2014) pp 4-10.

140 Bilchitz and Deva, "The Human Rights Obligations of Business: A Critical Framework for the Future" (2014) (fn 139) 6-8.

141 Draft Norms (fn 24). While the Draft Norms were unanimously adopted by the Sub-Commission on the Promotion and Protection of Human Rights, they were not adopted by the Commission on Human Rights. For a discussion of the process and substance of the Draft Norms see David Weissbrodt and Muria Kruger, "Norms of the Responsibilities of Transnational Corporations and Other Business Enterprises with Regard to Human Rights" (2003) 97(4) AJIL 901.

142 Weissbrodt and Kruger, "Norms of the Responsibilities of Transnational Corporations and Other Business Enterprises with Regard to Human Rights" (2003) (fn 141) 913-15. See also Muchlinski, Multinational Enterprises and the Law (2007) (fn 23) pp 531-534.

${ }_{143}$ Weissbrodt and Kruger, "Norms of the Responsibilities of Transnational Corporations and Other Business Enterprises with Regard to Human Rights" (2003) (fn 141) 914-15; Nolan, "The Corporate Responsibility to Respect Human Rights: Soft Law or Not Law?" (2014) (fn 129) 151.

144 Weissbrodt and Kruger, "Norms of the Responsibilities of Transnational Corporations and Other Business Enterprises with Regard to Human Rights" (2003) (fn 141) 915-21. 
ing as to the validity of pursuing a binding normative instrument directed at business. ${ }^{145}$ Unsurprisingly, the business community was particularly opposed to the Norms. Ultimately, they were not adopted by the Commission on Human Rights, which instead stated that the Norms had "no legal standing", ${ }^{46}$

It has been suggested that a cause of the divisions created by the Draft Norms was the lack of sufficient engagement with businesses in the process of the Norms' development. ${ }^{147}$ Another argument is that the failure of the Draft Norms and subsequent success of the SRSG process is rooted primarily in the SRSG distancing his project from more radical and substantive business accountability. ${ }^{148}$ Whatever is the case, it is clear that the polarisation caused by the Norms project fundamentally shaped the politics of UN efforts regarding business and human rights thereafter. It was in the wake of the controversy regarding the Draft Norms that the Commission on Human Rights appointed Professor John Ruggie as the SRSG, to assess developments on business and human rights to date and to propose the best ways in which the international community should go forward into the future. ${ }^{149}$ The SRSG's mandate and mode of operation were influenced by the stalemate created by the Norms and, in particular, by the belief that in order to transcend the stalemate, the SRSG's work would need to be the product of a highly participatory process. ${ }^{150}$

145 The SRSG described the Draft Norms as having "triggered a deeply divisive debate between the business community and human rights advocacy groups while evoking little support from Governments": Guiding Principles (fn 123) [3]. See also, John Gerard Ruggie, Just Business: Multinational Corporations and Human Rights (WW Norton \& Co 2013) pp xix-xx. For an outline of the Draft Norms, their relationship to the work of the SRSG, and the political debates they have engendered, see David Kinley et al, "The Politics of Corporate Social Responsibility: Reflections on the United Nations Human Rights Norms for Corporations” (2007) 25 C\&SLJ 30.

146 UNCHR, "Responsibilities of Transnational Corporations and Related Business Enterprises with Regard to Human Rights" (22 April 2004) UN Doc E/CN.4/ DEC/2004/116.

147 Karin Buhmann, "The Development of the 'UN Framework': A Pragmatic Process towards a Pragmatic Output" in Radu Mares (ed), The UN Guiding Principles on Business and Human Rights: Foundations and Implementation (Martinus Nijhoff 2011) p 101.

148 See, e.g. Parker and Howe, "Ruggie's Diplomatic Project and Its Missing Regulatory Infrastructure" (2012) (fn 137) 279-83.

149 The SRSG's original mandate is set out in UNCHR, "Human Rights and Transnational Corporations and Other Business Enterprises" (20 April 2005) UN Doc. E/CN.4/RES/2005/69. The UNHRC extended the SRSG's mandate for a further three years in 2008: UNHRC, "Mandate of the Special Representative of the Secretary-General on the Issue of Human Rights and Transnational Corporations and Other Business Enterprises" (18 June 2008) UN Doc. A/HRC/RES/8/7, 18 June 2008.

150 Parker and Howe, "Ruggie's Diplomatic Project and Its Missing Regulatory Infrastructure" (2012) (fn 137) 276-7. On the consultative nature of the SRSG's mode 
Very early in his mandate, the SRSG committed what he describes as "Normicide"; 151 rejecting the claim that corporations are directly bound by existing human rights law and criticising the Draft Norms process of identifying the content of such corporate human rights duties. ${ }^{152}$ The SRSG also rejected the pursuit of a formal binding treaty, taking the view that to act otherwise had the potential to undermine more effective shorter-term efforts to improve corporate human rights compliance. ${ }^{153}$ Instead, at the completion of his mandate in 2011, the SRSG had developed two principal documents to guide international action in respect of business and human rights. The first was a "Protect, Respect and Remedy Framework" (the Framework) setting out an overarching policy guide on business and human rights at an international level. ${ }^{154}$ The Framework comprises three pillars: the state duty to protect against human rights abuses by third parties; the corporate responsibility to respect human rights through due diligence; and the right of victims of corporate-related human rights abuses to have access to effective remedies. The Framework is further supplemented by a set of Guiding Principles, which provide guidance as to measures that should be adopted to enable states and businesses to operationalise the policy goals of the Framework. ${ }^{155}$

The Framework and Guiding Principles are firmly state-centric, fixing all legal obligations upon states in respect of the human rights compliance of business and ascribing to corporations the lesser "responsibility" to respect human rights. In terms of the state duty to protect, the SRSG describes as the key to change that governments "drive the business and human rights agenda more deeply into policy domains that directly shape business practices". ${ }^{156}$ In other words, states must mainstream human rights into domestic law, policies and practices across all government departments, but particularly those related

of operation and arguing that this has had an important impact upon its uptake, see Buhmann, "The Development of the 'UN Framework': A Pragmatic Process towards a Pragmatic Output" (2011) (fn 147).

151 Ruggie, Just Business: Multinational Corporations and Human Rights (2013) (fn 145) p 54.

152 UNHRC (n 136) [59]-[69]; John Gerard Ruggie, "Current DevelopmentsBusiness and Human Rights: The Evolving International Agenda" (2007) 101 AJIL 819, 822-33.

${ }^{153}$ For a discussion of the SRSG's position on the option of pursuing a treaty, see Ramasastry, "Closing the Governance Gap in the Business and Human Rights Arena: Lessons from the Anti-Corruption Movement" (2014) (fn 125) 169-72.

154 Framework (fn 2).

155 Guiding Principles (fn 123).

156 UNHRC, "Business and Human Rights: Towards Operationalizing the 'Protect, Respect and Remedy' Framework, Report of the Special Representative of the Secretary-General on the Issue of Human Rights and Transnational Corporations and Other Business Enterprises" (22 April 2009) UN Doc A/HRC/11/13 [120]. 
to trade, development and foreign affairs, in order to create convergence and coherence in practices with the potential to affect business impacts on human rights. ${ }^{157}$

Unlike the state duty to protect human rights, which is grounded in the international legal obligations of states, the corporate responsibility to respect human rights under the Framework and Guiding Principles is self-consciously not law. ${ }^{158}$ Instead, the corporate responsibility to respect human rights is grounded in social expectations of good business, and so might alternatively be described as the company's social licence to operate. ${ }^{159}$ Transgressions are therefore amenable to accountability through the court of public opinion and not courts of law, though some transgressions may have domestic legal ramifications. Precisely where a breach of the corporate responsibility to respect human rights shifts from a breach of social expectation to a breach of law is not particularised by the SRSG, though in this respect international criminal law norms of complicity are potentially indicative. ${ }^{160}$ To meet their responsibility to respect human rights, corporations should conduct due diligence processes to ensure they are alert, and able to respond, to the human rights impacts of their activities. ${ }^{161}$ The responsibility also extends to putting in place grievance procedures, so that companies can respond to allegations that they have fallen short in their efforts. ${ }^{162}$ As noted, failures to do so are amenable to the court of public opinion, which can have an impact on company business. In short, this process translates into a business case for corporate human rights compliance.

The Framework and Guiding Principles have been lauded for a number of successes, which largely relate to the consensus endorsement and uptake they received from the key stakeholders of business and states. ${ }^{163}$ However, the Framework and Guiding Principles are not without their critics. For example, the grounding of the corporate responsibility to respect in social expectation and not in legal or moral norms has led some to query whether and how it differs from other soft law measures that precede it. There are concerns that the limitations of voluntarism that have permeated the field to date will simply

157 Framework (fn 2), [33]-[42]; Guiding Principles (fn 123), Principles 4, 9 and 7.

158 Nolan, "The Corporate Responsibility to Respect Human Rights: Soft Law or Not Law?" (2014) 154-60.

159 Framework (fn 2), [54].

160 Surya Deva, "Guiding Principles on Business and Human Rights: Implications for Companies" (2012) 9(2) ECL 101.

161 Framework (fn 2) [56].

162 Framework (fn 2) [59].

163 For an outline of endorsement and critiques of the Guiding Principles, see Robert C. Blitt, "Beyond Ruggie's Guiding Principles on Business and Human Rights: Charting an Embracive Approach to Corporate Human Rights Compliance" (2012) 48 Tex.Int'l L.J. 33, 50-55. 
continue in this most recent iteration of corporate social responsibility in global economic regulation. ${ }^{164}$ For example, Simons argues that the Framework does not transcend the limits that inhere to the status quo because the SRSG ultimately failed to address the root causes of the governance gap he identified. For Simons, the SRSG retreats from his premise of a gap in governance to a position that rests upon a simple faith that there will be a change of behaviours by states and businesses in ways they have proven historically unwilling and unable to do, rather than his setting out reforms that will push back against structurally embedded corporate human rights impunity. ${ }^{165}$ Bilchitz goes further, arguing that the SRSG has taken corporate accountability efforts backwards when we consider that the way in which international initiatives are framed influences the progressive development of international law. ${ }^{166}$

Another concern that arises from the SRSG's choice to base corporate responsibility upon social expectation, is that it is based on an unduly limited view of the relationship between the development of social and legal norms. The SRSG presumes a unidirectional relationship between the advancement of social and legal norms, positing that the former must evolve before the latter will be effective. In other words, the SRSG posits that evolutions and cementation of social expectations regarding business and human rights are a necessary precedent to the introduction of effective law. However, legal and social normative advancement flows in both directions. While "social change pulls the law ... the law pushes society". ${ }^{167}$ The role of international law in advancing social expectations of business behaviour in the global economy, particularly in those countries where social expectation may be very low as a result of practice to date, is radically undermined in the SRSG's approach. ${ }^{168}$

Whatever one's view on the SRSG's Framework, the retreat from corporate duties grounded in international law and the move away from the goal of a business and human rights treaty means that the SRSG's special treatment of international crimes was particularly significant. From early in his mandate, the SRSG identified particular legal risks for business actors complicit in international crimes. Whilst not explicitly stating that corporations are directly

164 Nolan, "The Corporate Responsibility to Respect Human Rights: Soft Law or Not Law?" (2014) (fn 129) 154-60.

165 Simons, "International Law's Invisible Hand and the Future of Corporate Accountability for Violations of Human Rights" (2012) (fn 92).

166 Bilchitz, "A Chasm Between 'Is' and 'Ought'? A critique of the Normative Foundations of the SRSG's Framework and Guiding Principles” (2014) (fn 69) 116-7. 167 Adiva Sifris, "Lesbian Parenting in Australia: Demosprudence and Legal Change" in Paula Gerber and Adiva Sifris (eds), Current Trends in the Regulation of Same-Sex Relationships (The Federation Press 2011) p 15.

168 Bilchitz, "A Chasm Between 'Is' and 'Ought'? A critique of the Normative Foundations of the SRSG's Framework and Guiding Principles" (2014) (fn 69) 122-23. 
bound by the norms of international criminal law, he went as close as is otherwise possible to making that case. For example, in his 2007 report, the SRSG noted that "long-standing doctrinal arguments over whether corporations could be 'subjects' of international law ... are yielding to new realities"169 and that "the absence of an international accountability mechanism ... does not preclude the emergence of corporate responsibility today". ${ }^{170}$ Focusing in particular upon two parallel developments, the SRSG highlighted that the "simple laws of probability alone suggest that corporations will be subject to increased liability for international crimes in the future". ${ }^{171}$ The first of these two developments is the growing international criminal jurisprudence as to forms of criminal responsibility. This jurisprudence serves as guidance as to when business actors, individual or corporate, can commit international crimes. The second development is the growing number of states with jurisdiction within their national courts to try corporations, as well as individuals, for international crimes. This refers in particular to the member states of the ICC that have introduced Rome Statute crimes into their domestic criminal codes. According to the SRSG, the interplay between these two developments creates "an expanding web of potential corporate liability for international crimes". ${ }^{172}$ A number of commentators have therefore highlighted the special case of international crimes in the SRSG's work, identifying these norms as an exception from the SRSG's reluctance to otherwise articulate directly binding human rights norms on corporations under international law. ${ }^{173}$

In short, the SRSG has pointed to developments in international criminal law to blunt the implications of his otherwise rejection of corporate human rights duties under international law. He indicates a certain faith that international criminal law norms and the promise of accountability that flow therefrom will provide a modicum of legal corporate accountability, at least for corporate participation in the worst human rights abuses. International criminal law is thus seen to promise the enforcement of certain minimum norms against corporations in ways that international human rights law does not do and, additionally, that international human rights law is further away from doing as a result of the SRSG's retreat from binding law. It is worth noting, however, that in the

169 UNHRC (fn 68) [20].

170 UNHRC (fn 68) [21].

171 UNHRC (fn 68) [27].

172 UNHRC (fn 68) [22].

173 See, e.g. Sara L. Seck, "Collective Responsibility and Transnational Corporate Conduct" in Tracy Isaacs and Richard Vernon (eds), Accountability for Collective Wrongdoing (CUP 2011) pp 140-141, 150-151 and 157; Simons, "International Law's Invisible Hand and the Future of Corporate Accountability for Violations of Human Rights" (2012) (fn 92) 9-10. 
years since the production of the Guiding Principles, moves in the direction of a binding treaty on business and human rights have re-commenced. ${ }^{174} \mathrm{At}$ the time of writing, a UN open-ended intergovernmental working group has produced a Second Revised Draft for a treaty on business and human rights. ${ }^{175}$ Notably, the Second Revised Draft envisages a unique role for the advancement, and application, of criminal law in respect of certain categories of human rights abuses. ${ }^{176}$ Article $8(9)$ provides that:

Subject to their legal principles, States Parties shall ensure that their domestic law provides for the criminal or functionally equivalent liability of legal persons for human rights abuses that amount to criminal offences under international human rights law binding on the State Party, customary international law, or their domestic law. Regardless of the nature of the liability, States Parties shall ensure that the applicable penalties are commensurate with the gravity of the offence. States Parties shall individually or jointly advance their criminal law to ensure that the criminal offences covered in the listed areas of international law are recognized as such under their domestic criminal legislation and that legal persons can be held criminally or administratively liable for them. This article shall apply without prejudice to any other international instrument which requires or establishes the criminal or administrative liability of legal persons for other offences.

The prospects of a business and human rights treaty being realised remain speculative, but the work towards this goal demonstrates emerging consensus as to the appropriate way forward to deal with the challenges of ensuring global business is consistent with human rights. The final section below now turns briefly to the apparent promise and limitations of international criminal law as a business and human rights enforcement tool, before the more detailed examinations of the following chapters.

174 The process commenced in 2013 when a group of southern states issued a joint statement to the Human Rights Council calling for renewed efforts towards a treaty on business and human rights. The statement was tabled by Ecuador and South Africa, and co-sponsored by Bolivia, Venezuela and Cuba: see, Olivier De Schutter, "Toward a New Treaty on Business and Human Rights" (2015) 1 BHRJ 41, 41-42. The Human Rights Council established an open-ended intergovernmental working group to elaborate an international binding treaty: UNHRC Res 26/9 (25 June 2014) UN Doc A/ HRC/26/L.22/Rev.1.

175 "Legally Binding Instrument to Regulate, in International Human Rights Law, the Activities of Transnational Corporations and other Business Enterprises", OEIGWG Chairmanship Second Revised Draft (6 August 2020).

176 For a discussion of how criminal law has a uniquely important role to play in state responses to gross human rights violations under international human rights law, see: Joanna Kyriakakis, "Atrocities and Victim Redress: The Opportunities and Challenges of International Criminal Justice" in Surya Deva and David Birchall (eds), Research Handbook on Business and Human Rights (Edward Elgar Publishing 2020) pp 511-520. 


\section{CORPORATIONS AND INTERNATIONAL CRIMINAL LAW}

\section{Drivers Animating Interest in International Criminal Law and Business}

Recent interest in the potential of international criminal law as a mechanism for corporate accountability has been animated by a number of factors. One driver emanates from the business and human rights dialogue, described above. International criminal law is resorted to as a means by which gaps in the enforcement of international human rights law might be filled. As Van den Herik and Černič explain, there are qualities of international criminal law that make it appear amenable to this role. ${ }^{177}$ Unlike a substantial proportion of human rights, which allow for some state discretion as to implementation methods, international criminal norms and the duties they create are relatively more concrete and succinct. Furthermore, they already apply to a non-state actor (individuals) in, relatively speaking, fairly explicit terms. The application of such norms to corporate persons is therefore (potentially) less complicated and involves less of a paradigm shift than proposals for vertical corporate human rights duties (though simultaneously they cover quite a small subset of human rights norms). ${ }^{178}$ Enforcement processes that appear in theory more readily extended to another non-state actor, alongside natural persons, are also more advanced in international criminal law. These include the greater acceptance of the state exercise of extraterritorial jurisdiction in respect of international criminal norms ${ }^{179}$ and extant international criminal institutions, the jurisdiction of which could be extended to address corporate offenders. ${ }^{180}$ There is also the benefit of a lack of limitation periods on prosecuting international crimes, meaning a person may still be called to account many years after atrocities in the event that circumstances have conspired to prevent timelier

177 Larissa van den Herik and Jernej Letnar Černič, "Regulating Corporations under International Law" (2010) 8(3) JJJCJ 725, 739-42.

178 van den Herik and Černič, "Regulating Corporations under International Law" (2010) 740-41.

179 van den Herik and Černič, "Regulating Corporations under International Law" (2010) 740. The authors also note, however, that the unique politics that press against states exercising extraterritorial jurisdiction over non-national corporations in general may simply be transposed to state extraterritorial international criminal law enforcement efforts against them.

180 See, e.g. Martin-Joe Ezeudu, "Revisiting Corporate Violations of Human Rights in Nigeria's Niger Delta Region: Canvassing the Potential Role of the International Criminal Court" (2011) 11(1) AHRLJ 23; Jordan Sundell, "Ill-Gotten Gains: The Case for International Corporate Criminal Liability" (2011) 20 Minnesota J Int L 648, 675-78. 
prosecution. ${ }^{181}$ More generally, a number of commentators have noted the turn to penal law within human rights law discourse as part of an anti-impunity trend. ${ }^{182}$

Another driver, quite distinct from the dynamic described above, is the very nature of modern conflicts and the ways in which these are increasingly linked to economic actors and economic agendas. Many modern conflicts are intimately connected to economics, so the potential relevance of the field of international criminal law to business actors becomes more pronounced. ${ }^{183}$ International criminal law, whilst not limited to conflict situations, is in part an outgrowth of international humanitarian law's concern with regulating the worst excesses of armed conflict. The peace and security paradigm has therefore been described as the "traditional theatre of operation in international criminal law". ${ }^{184}$ Intimacy between conflict and business implies that relevant business transactions ought to come within the gaze of atrocity law.

There is a large body of academic literature on the economic dimensions of conflict or the phenomenon of so-called resource wars. Natural resources have been shown to be intimately linked to many contemporary conflicts: by providing the means to finance war; by prolonging conflict and increasing the chance of its recurrence; and by playing a role in the outbreak of armed conflict. ${ }^{185}$ Because of their necessary involvement throughout almost all stages of natural resource exploitation, from production to global distribution, corporations (and often transnational corporations in particular due to the need for foreign technology and expertise) are implicated in resource conflict dynamics. This may be in direct terms, for example by doing business with armed groups, or indirectly, by purchasing conflict resources as part of a supply chain towards producing consumer goods. ${ }^{186}$ As a result, there have been calls for a new

181 ICJ 2008 (fn 19) 54-55.

182 Karen Engle, "Anti-Impunity and the Turn to Criminal Law in Human Rights" (2015) 100 Cornell L Rev 1069; Mattia Pinto, "Historical Trends of Human Rights Gone Criminal" (2020) 42(4) Hum. Rts. Q. 729.

183 Larissa van den Herik and Daniëlla Dam-de Jong, "Revitalizing the Antique War Crime of Pillage: The Potential and Pitfalls of Using International Criminal Law to Address Illegal Resource Exploitation During Armed Conflict" (2011) 22(3) Crim.L.F. $237,238-50$.

184 van den Herik and Dam-de Jong, "Revitalizing the Antique War Crime of Pillage: The Potential and Pitfalls of Using International Criminal Law to Address Illegal Resource Exploitation During Armed Conflict" (2011) 245.

185 Daniëlla Dam-de Jong, International Law and Governance of Natural Resources in Conflict and Post-Conflict Situations (CUP 2015) pp 4-7, summarising the dynamics emerging from the literature.

186 Dam-de Jong, International Law and Governance of Natural Resources in Conflict and Post-Conflict Situations (2015) pp 18-21. 
generation of international criminal law that is directed particularly towards economic actors and economic crimes if it is to remain relevant in today's world. ${ }^{187}$

Schabas has argued that:

Economic agendas may contribute significantly to the outbreak and the perpetuation of war. It seems that in our post-Cold War context, civil wars are often little more than campaigns to acquire access to natural resources and markets, although somewhere in the distant past it may be possible to identify a role for ideological factors and political objectives. ${ }^{188}$

Economists have shed light on this perceived correlation between natural resource dependence, resource markets and conflict. There is a tendency in states economically dependent on natural resources to exhibit certain negative economic and political features that predispose those states to conflict. These features are often collectively referred to as the "resource curse" and they include: significantly lower economic growth compared to economies not rich in natural resources; ${ }^{189}$ higher corruption levels; ${ }^{190}$ a greater tendency toward authoritarian, dictatorial or unrepresentative government; ${ }^{191}$ and higher average military spending and militarisation. ${ }^{192}$

States that are economically dependent on natural resources are statistically more likely to suffer civil wars than other states, as well as civil wars of greater duration and intensity. ${ }^{193}$ There are a number of hypotheses as to why

187 van den Herik and Dam-de Jong, "Revitalizing the Antique War Crime of Pillage: The Potential and Pitfalls of Using International Criminal Law to Address Illegal Resource Exploitation During Armed Conflict” (2011) (fn 183) 249-50; Ifeonu Eberechi, "Armed Conflicts in Africa and Western Complicity: A Disincentive for African Union's Cooperation with the ICC" (2009) 3(1) African J L Studies 53.

188 William Schabas, "War Economies, Economic Actors, and International Criminal Law" in Karen Ballentine and Heiko Nitzschke (eds), Profiting from Peace: Managing the Resource Dimensions of Civil War (Lynne Rienner Publishers 2005) p 426.

189 Jeffrey D. Sachs and Andrew M. Warner, "The Curse of Natural Resources" (2001) 45 Eur Economic Rev 827.

190 Jeffrey D. Sachs and Andrew M. Warner, "Natural Resource Intensity and Economic Growth" in Jorg Mayer et al (eds), Development Policies in Natural Resource Economies (Edward Elgar Publishing 1999).

191 Michael L. Ross, "Does Oil Hinder Democracy?" (2001) 53(3) Wld.Pol. 325.

192 Michael L. Ross, Extractive Sectors and the Poor (Oxfam America 2001) p 15.

193 See, e.g. Paul Collier and Anke Hoeffler, "Greed and Grievance in Civil War" (2004) 56 Oxford Economic Papers 563; Paul Collier and Anke Hoeffler, "On Economic Causes of Civil War" (1998) 50 Oxford Economic Papers 563; Michael L. Ross, "What Do We Know About Natural Resources and Civil War?" (2004) 41(3) J. Peace Res. 337. 
this is the case. ${ }^{194}$ For example, resource dependence can generate a political economy dominated by the contest for control of resource "rents" or "rent seeking" that in turn can lead to corruption and violence. ${ }^{195}$ Natural resource dependence is also considered to promote the detachment of the government from the populace as the government becomes less dependent on tax revenue. This detachment of the government is in turn considered to hinder democratic development. ${ }^{196}$ Revenue generated by resource production may be used to finance war to the advantage of either or both government and rebel groups. This revenue provides the means for violence to continue or to be upgraded, or control of resources can be the goal of conflict itself. ${ }^{197}$ In relation to separatist civil wars, Michael Ross has proposed that "resource wealth tends to increase the casualty rate ... by giving the government an incentive to react to small challenges with unusually harsh countermeasures". ${ }^{198}$

Another way in which competition over natural resources may influence conflict is described by Thomas Pogge as a function of the global economic order and, in particular, the effect of the international resource privilege. This privilege refers to international practice whereby any group controlling the means of coercion within a country is globally recognised for the purpose of legally dealing with the country's natural resources. Such a group is legally empowered to confer rights in the country's resources irrespective of how their power was acquired. ${ }^{199}$ As a result Pogge posits that:

Indifferent to how governmental power is acquired, the international resource privilege provides powerful incentives toward coup attempts and civil wars in the resource-rich countries. ${ }^{200}$

194 For an assessment of some of the more common hypotheses regarding the causal nexus between natural resource dependence and civil war, see Michael L. Ross, "How Do Natural Resources Influence Civil War? Evidence from Thirteen Cases" (2004) 58 Int'l Org. 35.

195 Summarising views on the dynamic, see Paul Collier and Anke Hoeffler, "Resource Rents, Governance, and Conflict" (2005) 49 J Conflict Resol 625. Rent is a term used by economists to refer to the profits produced by an activity that are much higher than the minimum level needed to keep the activity going.

196 Collier and Hoeffler, "Resource Rents, Governance, and Conflict" (2005).

197 Philippe Le Billon, "The Political Ecology of War: Natural Resources and Armed Conflict” (2001) 20 Political Geography 561, 562.

198 Ross, "How Do Natural Resources Influence Civil War? Evidence from Thirteen Cases" (2004) (fn 194) 61.

199 Thomas W. Pogge, World Poverty and Human Rights, 2nd edn (Polity Press 2008) pp 118-22.

200 Pogge, World Poverty and Human Rights (2008) p 119. 
It is notable that it is in the contexts of conflicts involving significant natural resource implications within the war, such as the conflicts in Sierra Leone, Liberia and the Democratic Republic of the Congo, that peace and justice efforts have addressed the role of business and war economies within the war (see further Chs 4 and 5). Examples like these are discussed in the book and tend to demonstrate how the nature of conflict itself is driving the desire for corporate accountability under international criminal law to be realised institutionally.

\section{The Limitations of International Criminal Law for Capturing Business Conduct}

Despite these drivers, there is a risk of overemphasising the potential of international criminal law to bring about the human rights compliance of businesses and to serve as an accountability mechanism for corporate human rights abuses. This is due not only to the current lack of international criminal investigations and indictments towards the business case. It is also for the obvious reason that only a small subset of human rights violations constitute international crimes and only certain contributions to such violations invite criminal sanction. Moreover, criminal responsibility only flows if a high burden of proof is satisfied (beyond reasonable doubt), which can be difficult to do. A corporation's contribution to a human rights violation might legitimately invite some remedy but not meet the standard that warrants criminal punishment. International criminal law canvasses but a small segment of the field of concern, though the argument for legal — and even criminal — accountability is necessarily stronger in respect of its norms given the egregiousness of the wrongs it addresses. ${ }^{201}$

Schmid has also demonstrated that any analysis of international criminal law's capacity to respond to "economic abuses" depends crucially upon the type of economic elements present in a given case. She sets out a typology of economic abuses, categorised in terms of whether it is the actor, the harmful activity or the affected legal interests (or a combination of these) that are economic in kind. Each of these axes raises distinct challenges, with the presence of more than one of these characteristics in a case increasing its complexity and the limits of international criminal law. ${ }^{202}$ In other words, the challenges of pursuing a corporation or business official for involvement in a traditional international crime (namely one that threatens life and bodily integrity, such

201 See further Ch 6.

202 Evelyne Schmid, "Distinguishing Types of 'Economic Abuses': A ThreeDimensional Model" (2015) 26 Crim LF 225. 
as killing civilians) are different from those cases involving the harming of economic interests, such as rights to work or to property. ${ }^{203}$

Another problem for over-reliance on extant developments in international criminal law is that there may be grounds for cynicism with respect to the actual application of domestic law to corporations involved in international crimes in the territory of another state. The implementation of domestic international crimes laws and their extension to corporate legal persons, which the SRSG anticipates will lead to an increased web of corporate accountability, has been to a great part "an unanticipated by-product" of states strengthening their legal regimes for individuals. ${ }^{204}$ There remain doubts as to whether there will be the political will to apply these laws to businesses as legal entities, particularly in relation to events beyond the boundaries of the prospective adjudicative state. In that respect, it is telling to look at the recent fate of the United States Alien Tort Statute (ATS). To date, the ATS has been the most utilised law by victims of corporate human rights violations as a civil law remedy to what are essentially international criminal norms applied to the business dimensions of conflict. ${ }^{205}$ However, the Supreme Court of the United States has significantly curtailed the applicability of the ATS to transnational corporate human rights cases in recent years. ${ }^{206}$ Among other things, the Court's rejection of the law's extraterritorial implications in respect of corporate misconduct was influenced by sovereignty concerns voiced by states over the application of US jurisdiction over so-called "foreign cubed" cases, namely cases where the events in question did not occur in the US and neither the victim nor the offender were substantially linked to the US. ${ }^{207}$ The fate of the ATS suggests grounds to doubt faith in the potential of unilateral state responses to business violations

203 Schmid, "Distinguishing Types of 'Economic Abuses': A Three-Dimensional Model" (2015).

204 UNHRC (fn 68) [84]. See also Joanna Kyriakakis, “Australian Prosecution of Corporations for International Crimes: the Potential of the Commonwealth Criminal Code" (2007) 5(4) JICJ 809, discussing the Australian example in particular.

205 For a discussion of the relationship between the Alien Tort Statute and the norms of international criminal law as applied to corporations, see Katherine Gallagher, "Civil Litigation and Transnational Business: An Alien Tort Statute Primer" (2010) 8(3) JICJ 745 .

206 Kiobel v Royal Dutch Petroleum, 133 S.Ct. 1659 (2013); Jesner v Arab Bank Plc, 138 S.Ct. 1386 (2018).

207 See, e.g. Kiobel v Royal Dutch Petroleum, 133 S.Ct. 1659 (2013) 1669, Roberts CJ listing the objections of other states to extraterritorial applications of the ATS as evidence of the diplomatic strife such claims engender. The fate of a Belgian law of 1993 on serious crimes against international humanitarian law illustrates something similar, where international and industry pressure led to the winding back of Belgian universal jurisdiction over international crimes: De Schutter, "The Accountability of Multinationals for Human Rights Violations in European Law” (2005) (fn 63) 287-88. 
of international criminal law on the basis of domestic international crimes laws that exist on paper but have yet to be tested in practice.

Putting aside the tensions engendered by unilateral state adjudicative jurisdiction over cases with little to no link to the forum, for many, international criminal law is not the most intuitive "fit" to regulate corporate actors. The idea of corporate criminality, meaning the capacity of corporate entities to offend against criminal law, has been either excluded or marginalised in many modern domestic criminal justice systems. A number of continental countries, for example, retain a notion known as societas delinquere non potest, meaning that corporations cannot commit a criminal offence. ${ }^{208}$ This notion comprises at least two claims. First, only individual human beings are the proper subjects of criminal judgment, because only humans can act wilfully or intentionally. Second, only human beings are proper subjects of criminal punishment, as it is a uniquely human capacity to make moral determinations of what is right and what is wrong. ${ }^{209}$ A sentiment of this kind is reflected in the famous statement of the Lord Chancellor of England who, when faced with a convicted corporation, is reported to have said, "did you ever expect a corporation to have a conscience, when it has no soul to be damned, and no body to be kicked?"210 While there is evidence that domestic recognition of corporate criminal liability is converging, ${ }^{211}$ evidence of its actual application to intent crimes remains limited.

Indeed, even in legal traditions that have long considered corporations appropriate subjects of criminal law, "white collar" and corporate crime has been marginalised. ${ }^{212}$ Among other things, corporate misconduct in those legal

208 For an overview of various national approaches to corporate criminal liability across the civil and common law divide, and noting the increasing convergence towards recognition of corporate criminal liability in domestic law, see Joanna Kyriakakis, "Comparative Criminal Liability and the ICC Statute: The Comparative Law Challenge” (2009) 56(3) NILR 333, 333-53.

209 Gerhard Fieberg, "National Developments in Germany: An Overview" in Albin Eser et al (eds), Criminal Responsibility of Legal and Collective Entities: International Colloquium, Berlin, May 4-6, 1998 (Freiburg im Breisgau 1999) p 86.

210 Quoted in John C. Coffee Jr, "'No Soul to Damn: No Body to Kick': An Unscandalized Inquiry into the Problem of Corporate Punishment" (1981) 79(3) Mich.L.Rev. 386, 386. Coffee notes that some accounts of this statement report that the Lord Chancellor added, "[a]nd, by God, it ought to have both".

211 See, e.g. Kyriakakis, "Comparative Criminal Liability and the ICC Statute: The Comparative Law Challenge” (2009) (fn 208).

212 See, e.g. Celia Wells and Oliver Quick, Lacey, Wells and Quick Reconstructing Criminal Law: Text and Materials, 4th edn (CUP 2010) pp 673-678; Maurice Punch, "Why Corporations Kill and Get Away with it: The Failure of Law to Cope with Crime in Organisations" in André Nollkaemper and Harmen van der Wilt (eds), System Criminality in International Law (CUP 2009) p 42. 
systems tends to be predominantly dealt with under the rubric of regulatory offences. As Lacey and Quick point out, certain characteristics of the regulatory model reflect and reinforce a view that the behaviour being addressed is less serious, less truly criminal, than the core of the criminal law. ${ }^{213}$ Both the outright exclusion of corporations from the ambit of criminal law and their marginalisation within the field are in essence functions of the same thing. As Wells puts it, "the language and ideas of criminal law are in the grip of individualism". ${ }^{214}$ So to turn to criminal law as a response to corporate misconduct, as opposed to civil, administrative or other regulatory mechanisms, can seem counterintuitive.

Another distinct layer of controversy regarding the relevance of international criminal law to corporate actors emanates from the "international" dimensions of the field. Conversely to the criminal law's fetishism of individualism, internationally the unit of most significance is the state. Modern international law orthodoxy claims that states are the sole proper subjects of international law. This is a reflection of the very distinct way in which international law is created and its traditional purview. According to the orthodox view, any deviations from this norm, such as individual (human) criminal responsibility under international criminal law or the recognition of international organisations as partial international legal persons, are exceptional. For this reason, the claim that international criminal law does and should apply to corporations, not only natural persons, offends orthodoxy as it reads a wider ambit into the so-called exceptional recognition of the individual under international law. These kinds of prominent critiques and challenges to the proposal to direct international criminal law to corporations and business actors are analysed in detail in Chapter 6.

\section{STRUCTURE OF THE BOOK}

The next chapters proceed as follows. Chapter 2 focuses on the ways that industry was integral to the trial programs adopted at Nuremberg and Tokyo as a response to the German and Japanese atrocities in World War II and how industry was otherwise the subject of legal sanction in post-war reconstruction. Drawing on material recently made available by legal historians, this chapter sets out the models of responsibility adopted the Allied post-war criminal justice programs, revisits the key trials of German industrialists within those

213 Wells and Quick, Lacey, Wells and Quick Reconstructing Criminal Law: Text and Materials (2010) (fn 212) pp 661-673. See also, Celia Wells, Corporations and Criminal Responsibility, 2nd edn (OUP 2001) Chs 1, 2 and 4.

214 Wells, Corporations and Criminal Responsibility (2001) p 14. 
programs, as well as then exploring how corporations were separately the subject of administrative seizures of assets and dissolution. The chapter explores the competing interpretations of this history in terms of its implications for the modern corporate accountability movement, identifying strengths and weaknesses in the perspectives advanced on both sides of that debate.

Chapter 3 turns to the ICC and in particular debates towards the inclusion of corporations in the jurisdiction of that Court. It sets out the history of discussions towards a permanent international criminal court and where the issue of corporate liability arose, and outlines the models and debates explored during the Rome Conference that led to the establishment of the Court. The chapter then examines arguments that have been presented in favour and against the proposal, analysing in particular the critique that corporate criminal responsibility at the ICC would be inconsistent with the Court's foundational principle of complementarity, namely, the principle that the Court must operate in a way that complements the activities of domestic criminal justice systems.

Chapter 4 moves to explore cases and initiatives that address business actors in the work of international criminal institutions other than the ICC and in the post-World War II context, focusing upon particularly noteworthy cases or developments. These are: cases and initiatives at the International Criminal Tribunal for Rwanda; the Special Court for Sierra Leone; the Special Tribunal for Lebanon; efforts towards a prospective African Criminal Court; and developments in domestic criminal courts directed towards international crimes. Because the effort to engage with business in international criminal practice to date has principally been in the form of pursuing individual business actors, the chapter is focussed in large part upon such cases. However, it also identifies initiatives directed specifically at the corporation as the offender.

Chapter 5 turns attention to the broader field of transitional justice, looking at ways in which modalities of justice other than international criminal justice have been used in post-conflict and post-abuse contexts to address the role of industry in atrocity and to seek some form of business accountability for international crimes. This chapter discusses the general marginalisation of economic matters in transitional justice efforts to date. It then explores a few modalities of transitional justice and some of the key examples within those modalities that involve attempts to deal with the role of business in atrocity crimes, looking particularly at truth commissions and related proposals for state-based reparation schemes, UN Security Council sanctions and transnational civil litigation. Broad conclusions and lessons that might be drawn from the experience in the field of transitional justice in relation to corporate involvement in international crimes are discussed, together with their potential implications for the proposal that corporate accountability should form part of the international criminal justice project. 
Chapter 6 is the most substantial and lengthy of the chapters in this book. It analyses the key theoretical and doctrinal debates that relate to the feasibility and desirability of applying international criminal law to address the phenomenon of business involvement in international crime. It does so first, in terms of the proposal that international criminal law should be further and better directed towards prosecuting individuals in the business world who are closely enough involved with international crimes to warrant criminal responsibility and, second, in terms of the proposal that institutions enforcing international criminal law should be willing and able to prosecute corporations for such crimes, in appropriate circumstances. The discussion in Chapter 6 thus explores a wide range of critiques and concerns related to those two potential pathways for addressing the role of industry in atrocity as part of the international criminal justice project, teasing out the contours of distinct but overlapping debates about the feasibility and desirability of a turn in this direction within the project. Overall, it advances the view that there are challenges and risks associated with prosecutions of business individuals and corporations for involvement in atrocity, but that such a move, consciously pursued, is both possible and desirable, should political will allow it.

\section{CONCLUSION}

A fundamental challenge of the modern age is how to address corporate governance gaps, narrowing their parameters so as to limit the circumstances in which companies might adversely affect human rights without accounting for the wrong. As to the solution, opinions vary. For those who take the view that the problem is limited to rogue corporations that opportunistically take advantage of regulatory gaps, the solution may lie in efforts to harness social pressures upon businesses to comply with social norms and to encourage (rather than oblige) internalised corporate concern for rights. For those who take the view that the problem is endemic to our global economic organisation as driven by a neo liberal agenda, the solution is likely to require deep changes to the prevailing legal frameworks to push against structural flaws. Some argue a turn away from law entirely.

Whatever one's view, the role for international criminal law is an important dimension of this debate. The expectation that the principles and institutions of international criminal law will, at least in some part, reduce prevailing corporate impunity for human rights abuses is being generated both by the trajectory of international human rights frameworks and by the very nature of modern conflict. But, while human rights lawyers may sometimes see the application of international criminal law to business as relatively uncontroversial, this is not the case. Attention to the promise, and risks, of this field of law as a tool of corporate human rights accountability requires continued engagement. As 
Ratner argues, creating a fuller theory of corporate international liability is valuable not despite, but because of the predictability of state reticence to apply international criminal (or other human rights) law to business. As Ratner argues, in speaking in respect of the project to develop a cohesive theory of corporate human rights duties:

In the end, this exercise's strongest defence is its possibility of providing a framework and rationality to the dialogue of the deaf ... One of law's great purposes is to provide a set of bookends that exclude certain claims by various sides from the table and thereby narrow the range of differences. ${ }^{215}$

His statement is equally valid in respect of the role to be played by a coherent theory of international criminal law's application to business in curbing the excesses of corporate behaviour in the global economy.

215 Ratner, "Corporations and Human Rights: A Theory of Legal Responsibility" (2001) (fn 40) 544 (footnote omitted). 